\title{
The Kilen Expedition 1985
}

ECKART HÅKANSSON, TOVE BIRKELUND, CLAUS HEINBERG, CHRISTIAN HJORT, PER MØLGAARD \& STIG A. SCHACK PEDERSEN

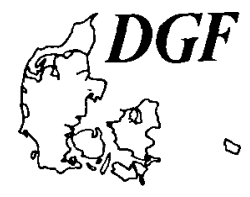

\begin{abstract}
Håkansson, E., Birkelund, T., Heinberg, C., Hjort, C., Mølgaard, P. \& Pedersen, S. A. S.: The Kilen Expedition 1985. Bull. geol. Soc. Denmark, Vol. 40, pp. 9-32, Copenhagen, June 3th, 1993. https://doi.org/1Ø.3757Ø/bgsd-1994-4Ø-Ø1

The 1985 expedition constitutes the first comprehensive investigation of the isolated, hyperarctic semi-nunatak Kilen in eastern North Greenland. Well over $3 \mathrm{~km}$ of generally marine, clastic sediments are preserved from the Late Jurassic to Late Cretaceous period. While half this amount accumulated in a comparatively stable tectonic regime prevailing during Late Jurassic and Early Cretaceous time, the Late Cretaceous (Turonian-Coniacian) sediments are characterized by their deposition in a local pull-apart basin developed in the regional Wandel Hav Strike-Slip Mobile Belt. Subsequent, localized compression along this belt has deformed the entire sequence rather severely in a complex series of en èchelon domal folding and thrusting, most likely during the later part of the Cretaceous. Quaternary marine sediments of probable interglacial origin ( $>100.000$ years old) have been found to contain a mollusc fauna requiring temperatures above the present level. Flade Isblink, the largest local icecap in Greenland, is composed of several semi-independant ice domes, and there is evidence that the history of this icecap deviates significantly from that of the Inland Ice. A total of 34 species of higher plants, 29 species of birds, and 11 species of mammals have been recorded from Kilen; vegetation studies indicate a July mean temperature of around $2.5^{\circ} \mathrm{C}$.
\end{abstract}

E. Håkansson, Dept. of Geology, University of Copenhagen, Øster Voldgade 10, DK-1350 Copenhagen K, Denmark. C. Heinberg, Roskilde University Center, P.O. Box 260, DK-4000 Roskilde, Denmark. C. Hjort, Dept. of Quaternary Geology, University of Lund, Sölvesgatan 13, S-22362 Lund, Sweden. P. Mølgaard, Dept. of Botany and Pharmacognosy, Royal Danish School of Pharmacy, Universitetsparken 2, DK-2100 Copenhagen Ø, Denmark. S. A. S. Pedersen, Geological Survey of Denmark, Thoravej 8, DK-2400 Copenhagen NV, Denmark. December 18th, 1992.

\section{Introduction}

A multidisciplinary expedition working in the desolete seminunatak Kilen in Kronprins Christian Land, North Greenland provided the logistic frame for the last of Tove Birkelunds contributions to the exploration of the geological history of Greenland. Quite appropriately this final effort was aimed specifically towards the very rich Late Cretaceous ammonite faunas recently recognised in Kilen.

\section{Explorational history}

The position of Kilen as a semi-nunatak wedged deeply into the second largest ice cap in Greenland just south of Nordostrundingen makes it one of the least inviting and least accessible areas in the Northern Hemisphere. When judged by reports from earlier expeditions this semi-nunatak must have had an exeedingly low esteeme among the few people travelling around the northeasternmost corner of Greenland. Hardly any report mentions its existence, and yet all parties travelling in these areas must have passed along or near the Kilen coast. The main reason for this situation is undoubtedly the combination of an extensive, very flat coastal plain and the substantial snow cover developed regularly along the open waters of the Nordøstvandet Polynya. To most dog-sledge parties the Kilen coast would hardly have been discernible from the surrounding flats of Flade Isblink itself, and from the coast the distant hills in the interior of Kilen are very inconspicuous, indeed, particularly when covered in snow.

The name Kilen (Danish for "the wedge") was applied by Dansk Nordøstgrønlands Expedition 1938-39 under the leadership of Ebbe Munch and Eigil Knuth (Knuth 1942). However, it was first used by Eigil Nielsen (1941), who led the only dog-sledge party of that expedition to reach as far north as Kilen.

Early interpretations of the geology were based entirely on airial photographs and observations from aircrafts, and the geological make-up of Kilen in earlier models was therefore fairly speculative, with distinct preferences towards older, i.e. Precambrian to Paleozoic, rocks (e.g. Haller 


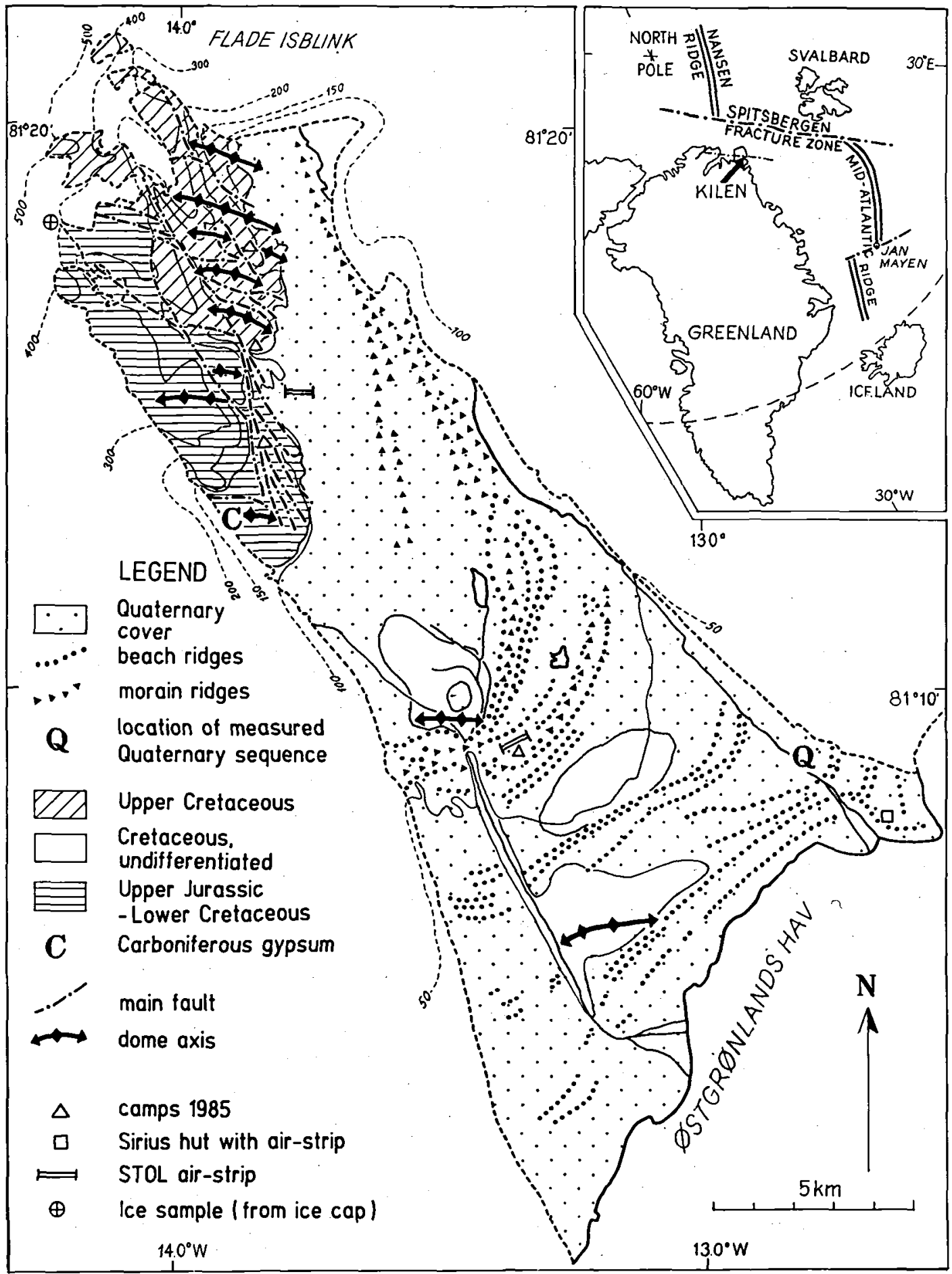

Fig. I. Geological sketch map of Kilen. The insert map shows the location of the semi-nunatak: Kilen and its position in a geotectonic context. 
1983; Henriksen \& Higgins 1976). It was not untill the summer of 1971 that the first primary geological piece of information was brought back after a brief helicopter reconnaiscence by a member of the Greenarctic Consortium investigation team. During this visit a few ammonite fragments of alledgedly Middle Jurassic age were collected from a series of fine-grained clastic sediments on the outer part of the coastal plain. On this background Kilen was incorporated in the geological development of the Carboniferous-Tertiary Wandel Sea Basin, although the main part of Kilen was still considered to be composed of older rocks (Dawes 1976).

In the summer 1980 four members of a Geological Survey of Greenland expedition (EH, CHe, PM, \& Lars Stemmerik) conducted a preliminary investigation, spending up to 7 days in Kilen. During this investigation it became apparent, that not only were the strata exposed in Kilen predominantly, if not entirely, of Late Jurassic to Late Cretaceous age, but also they seemed without obvious relations to sediments in other regions of Greenland (Håkansson et al. 1981b). Subsequently, also in the summer of 1980 , one member of the Ymer expedition ( $\mathrm{CHj}$ ) made a visit with a few helicopter groundstops, which revealed the presence of marine deposits of possibly early Pleistocene age (Hjort 1981). The very interesting geological and biological observations made during the two visits in 1980 were the principal incentive for carrying out the independant, mutidisciplinary Kilen Expedition in 1985 with support from the Carlsberg Foundation (to EH), the Danish Natural Science Research Council (to TB), and the Swedish Ymer Foundation (to $\mathrm{CHj}$ ).

\section{Expedition logistics}

The fairly high degree of specialisation among participants in the Kilen Expedition and the considerable area to be covered by each of these specialists called for an unusually high mobility and flexibility in the logistics of the expedition. Economic realities prevented the use/deployment of helicopters, and instead the necessary mobility was secured by a combination of fixed-wing STOL aircrafts ("Twin Otter") and three- wheeled, off-road Honda motorcycles with baloon tires.

From the Danish military base Station Nord the STOL aircrafts lifted the entire expedition in and out of the area via three landing sites, two of which were previously untested and unvisited on the ground (Fig. 1). Between depots established at the landing sites and short-time field-camps set up in near proximity to most important working areas exchange of people, provisions and samples was maintaned by the use of two motorcycles with a trailer. Nevertheless, actual field work was largely conducted on foot.

In view of the proxemity to the open waters of the Nordøstvandet Polynya - corrobated by our limited experience from the brief visits in August 1980 - a substantial and longlasting snowcover was expected. Consequently it was decided to postpone entry till late in July, hoping that the ground would then have dried out sufficiently to allow access. However, it was not until the last half of August that most of the plain became accessible on foot - even though the summer 1985 appears to have experienced unusually early and extensive snow melting all around Kronprins Christian Land.

By the end of August light was failing rapidly, forcing the expedition to withdraw to Station Nord and, consequently, a total of 27 days were available for actual field-work.

\section{Regional geology}

The accumulation of Carboniferous and younger sediments postdating the Caledonian and Ellesmerian Orogenies in North Greenland was unified in the Wandel Sea Basin by Dawes \& Soper (1973). In the wake of the large scale mapping campaign carried out in eastern North Greenland by the Geological Survey of Greenland in 1978 to 1980 a number of models for the regional development were proposed, including models pertaining to the Wandel Sea Basin (e.g. Håkansson \& Pedersen 1982; Soper et al. 1982). Among these attempts the geology of Kilen was of particular importance to the understanding of the regional Wandel Hav Strike-Slip Mobile Belt introduced by Håkansson \& Pedersen (1982), and the Kilen 1985 expedition has been essential to the subsequent refinement of this concept ( $\mathrm{Pe}$ - 


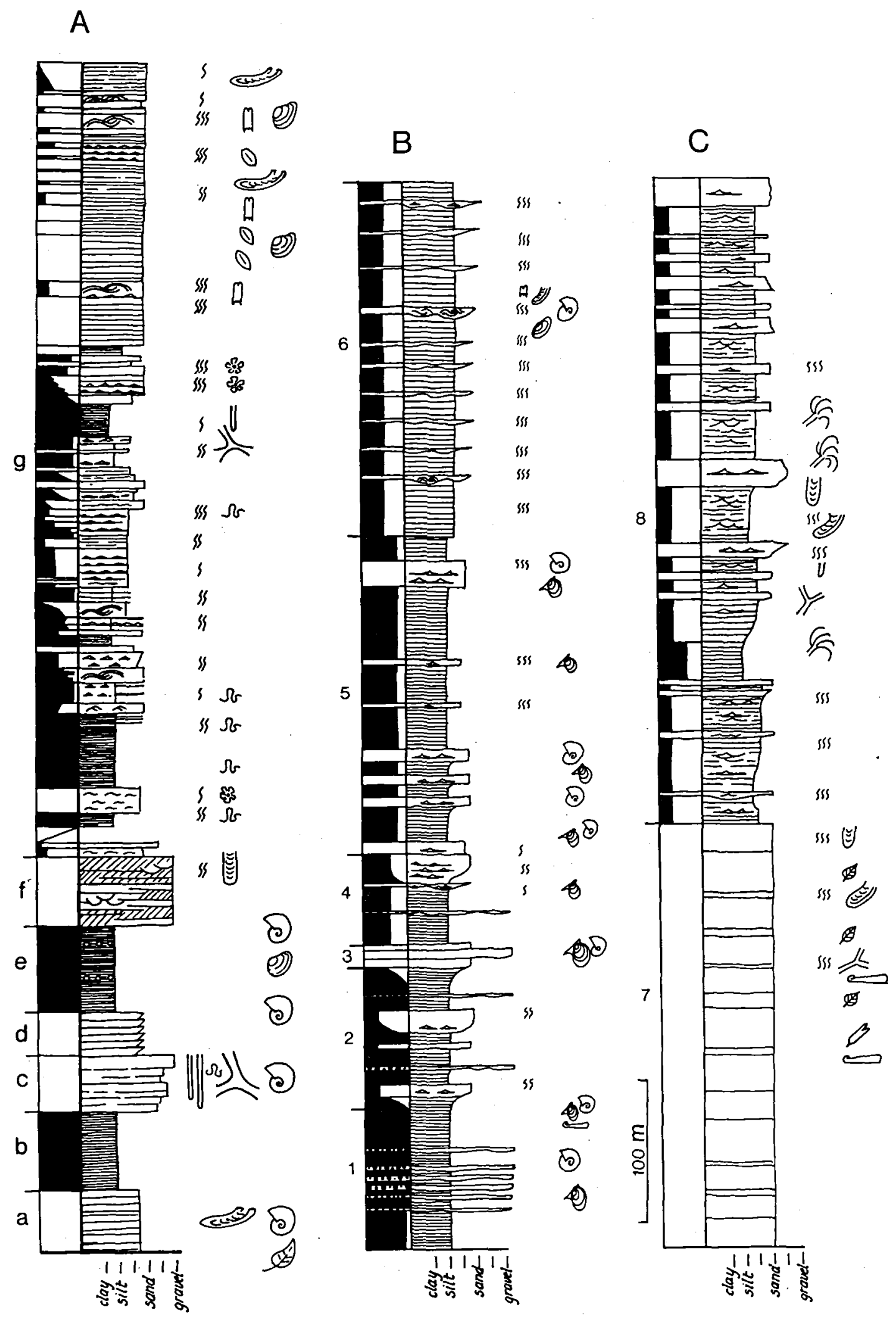




SEDIMENTARY
STRUCTURES

dersen 1988; Håkansson \& Stemmerik 1989; Håkansson et al. 1991, 1992). Three distinct structural phases have been recognised in the development of the Wandel Hav Strike-Slip Mobile Belt of which the two youngest are directly demonstrable in Kilen - the transtensional Kilen Event in the mid Cretaceous, and the transpressional Kronprins Christian Land Orogeny close to the Cretaceous/Tertiary boundary. The preceeding transpressional phase - the Ingeborg Event - is detectable only indirectly, as the structural background for the Jurassic basin formation.

In a larger, geotectonic perspective the structural regime expressed in the Wandel Hav StrikeSlip Mobile Belt is believed to reflect directly activities along the Mesozoic boundary between the Eurasian and the Laurentian plates (Håkansson et al. 1992 \& in prep.).

\section{Stratigraphy and sediments}

A total well over three kilometers of sediments have been encountered in Kilen. The formal designation of stratigraphic units in the sequences encountered in Kilen is in progress, and, similarly, a series of topographic names are pending approval by the Greenland names commision. Accordingly none of these new names will be referred to here.
Fig. 2. Lithostratigraphic log of the main Upper Jurassic - Lower Cretaceous (A) and Upper Cretaceous (B and C) sequence from the inner part of Kilen.

\section{Late Carboniferous}

Very limited occurrences of whitish gypsum with distinct grey banding and small amounts of very fine-grained, dark grey limestone were found distributed along one of the thrusts in inner Kilen. The sequence is severely deformed, and owing to the extreme difference in competence the exact relation between gypsum and limestone have not been determined. Enough is present, however, to suggest a direct correlation to the Upper Carboniferous gypsiferous strata known in undisturbed position from southern Amdrup Land (facies association c of Håkansson et al. 1981b) almost 100 $\mathrm{km}$ to the SW.

\section{Late Jurassic to Early Cretaceous in the inner part of Kilen}

The Upper Jurassic - Lower Cretaceous sequence of lagoonal to high energy coastal sediments measured in 1980 (units a - f, Fig. 2; Håkansson et al. 1981b) was reinvestigated, but the main objective was to study the remaining unit $\mathrm{g}$ - in some detail. An additional, almost complete sequence comprising the units $e$ (in part), $f$ and $g$ demonstrates that our previous estimate for $\mathrm{g}$ was, indeed, very accurate. The measured thickness is $550 \mathrm{~m}$ (in contrast to the $600 \mathrm{~m}$ estimated), and the overall coarsening upwards nature of the entire $g$ sequence was similarly sub- 


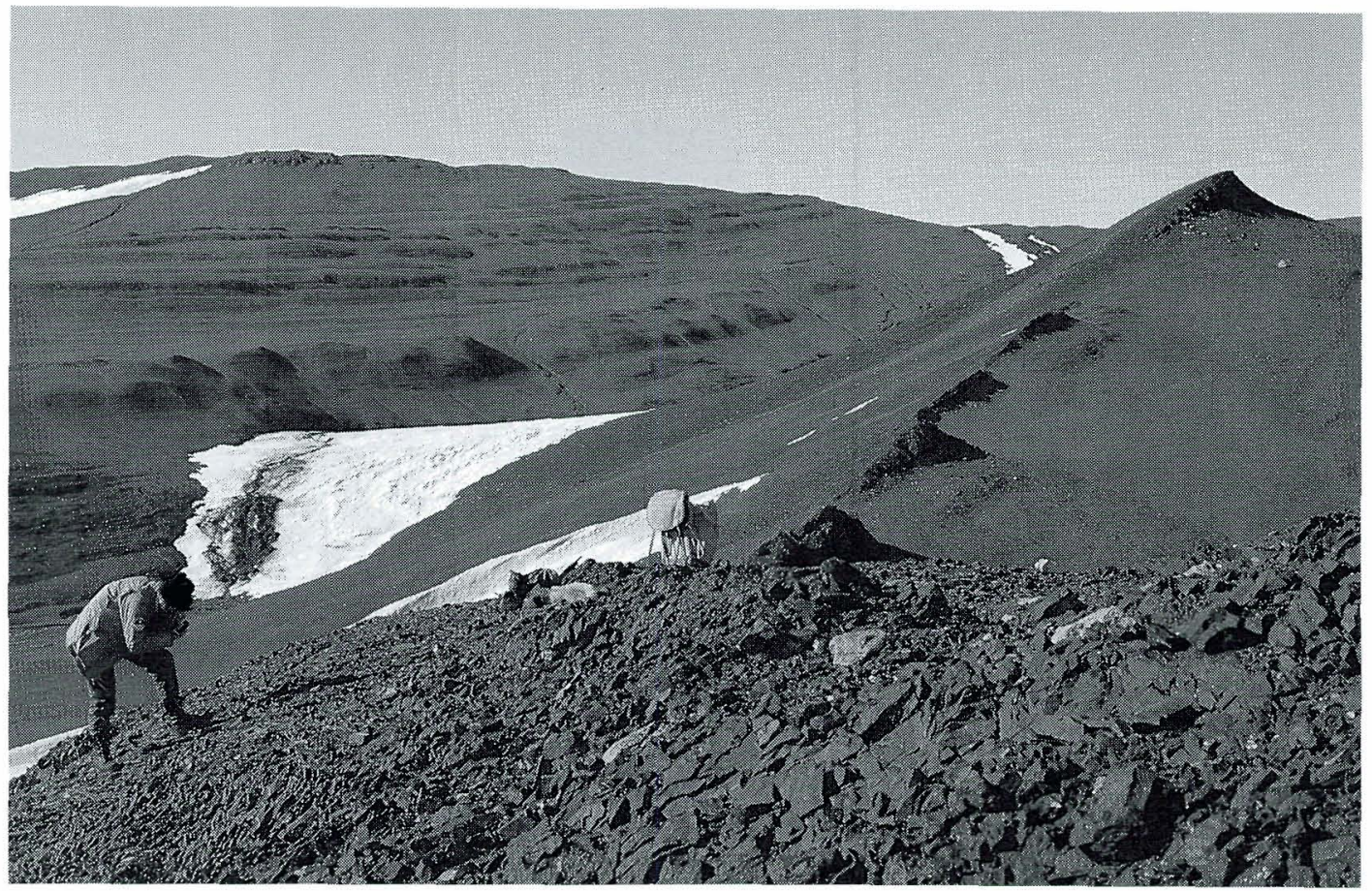

Fig. 3. Domal folding in Units 3 (forground slope) and 5 (background) of the Upper Cretaceous sequence from the inner part of Kilen.

stantiated (Fig. 2). A number of characteristic beds were identified, some of which proved valuable in precise lithostratigraphical correlation across the abundant faults. The most widely recognized marker bed is characterized by an abundance of the trace fossil Gyrophyllites, but also a horizon of abundant 'dog tooth spar' concretions (composed of gaylussite, O. Jørgensen, personal communication 1985) apparently has lithostratigraphical significance.

A very significant sedimentological feature of the $\mathrm{g}$ unit is the abundance of hummocky bedded sandstone units, both in the shaly and the sandy parts. The base of the hummocky sandstones often shows parallel striation marks. Similarly, striation marks and groove marks were found in association with the repetitive interbedding of dark wavy bedded sandstone units into the otherwise platy, light coloured sandstones in the upper part of the sequence. These dark horizons also contained abundant bivalve resting traces (Pelecypodichnus).

No determinable body fossils have been found in $g$, and the age is therefore uncertain. In the lower part of the sequence ammonites character- izing the Lower Kimmeridgian Rasenia cymodoce Zone have been identified in a, the Middle Volgian Dorsoplanites gracilis Zone in c, and ammonites of the Lower Valangian Polyptychites michailskii Zone have been described from e by Birkelund \& Håkansson (1983).

A very limited occurrence of multicoloured sandstones and sandy shales seemingly unrelated to any other known unit in the Wandel Sea Basin was found as a structural wedge emplaced between Lower and Upper Cretaceous sediments. Middle to Upper Volgian ?Paracraspedites sp. were collected from the sandstones.

\section{Late Cretaceous in the inner part of Kilen}

The marine sequence of Middle Turonian to Early Coniacian age found in 1980 (Håkansson et al. 1981b; Kauffman in Birkelund \& Håkansson 1983 ) is of particular interest in view of the fact that marine Upper Cretaceous outcrops are very 
sporadic in the high Arctic. The 1985 field work expanded the known thickness of these deposits to a total close to $1500 \mathrm{~m}$ without significantly extending the stratigraphic range. The sequence comprises a number of lithological units, mostly recognizable even in poorly exposed areas owing to well developed marker beds, most of which yield rich faunas. Of special interest are profuse occurrences of members of the European Scaphites geinitzii group throughout large parts of the sequence, which permit a detailed analysis of the morphological range of variation through time. In Europe, inadequate stratigraphical information and condensed occurrences (first and foremost in the English Chalk Rock; cf. Wright 1979 ; Bromley \& Gale 1982) up to now has prevented such analyses within this group. Eight distinct units have been identified (Fig. 2).

Unit 1 consists of some $100 \mathrm{~m}$ dark, often pyritic, silty shale with scattered sideritic nodules and horizons, commonly associated with thin, matrix-supported conglomerates. The conglomerates contain pebbles of quartzite, phosphorite, and shales. Ripple-laminated, very fine-grained storm-sand horizons occur throughout the sequence. Fossils (Scaphites, Sciponoceras, and inoceramid bivalves) indicative of a Middle Turonian age are common in the middle and upper parts.

Unit 2 is some $100 \mathrm{~m}$ thick and generally more sandy than unit 1 . It includes three upwardscoarsening sequences with two prominent sandstone markers. These markers consist of thin, ripple-laminated storm-sandstones and siltstones below, and up to $20 \mathrm{~cm}$ thick ripple-laminated, very fine-grained sandstone beds and subordinate siltstones above. The two silty shale intervals are characterized by fine storm-sand layers and, in both of them, there is a thin sideritic conglomerate with matrix-supported pebbles of quartzite and phosphoritic nodules very similar to the conglomerates in unit 1. Middle Turonian Scaphites and inoceramid bivalves abound throughout the unit together with a few belemnites.

Unit 3 is a widely recognizable, c. $10 \mathrm{~m}$ thick resistant sideritic sandstone and conglomerate marker. At the base it consists of greenish weathering, fine-grained ripple-laminated sandstone with scattered phosphoritic clasts, whereas in the upper, sideritic part conglomerates become more prominent with quartzitic, phosphoritic, and sideritic pebbles, in addition to shale clasts. Large inoceramid bivalves and Puzosia s.l. indicating a Middle Turonian age have been found.

Unit 4 is very uniform, consisting of an upward coarsening sequence of some $65 \mathrm{~m}$ greyish silty shale with storm-sand layers throughout, topped by c. $10 \mathrm{~m}$ thick sandstone. Sideritic nodules are sporadic, but $15 \mathrm{~m}$ above the base a sideritic nodule horizon with pebbles of quartzite and phosphorite is seen. The top sandstone is characterized by scattered, large sideritic concretions and carbonaceous debris. Inoceramid biyalves in the lower part indicate a ?Middle to Late Turonian age.

Unit 5 is $160 \mathrm{~m}$ thick and dominated by silty deposits intercalated by five prominent sandstone markers. The markers are more or less glauconitic and characterized by small-scale or largescale cross-bedding; sideritic concretions are common in their top parts. The rich faunas, dominated by Scaphites and inoceramid bivalves, are concentrated at the top of the glauconitic sandstones. The age through the unit ranges from the Late Turonian into the Early Coniacian.

Unit 6 is not well exposed. It consists of some $250 \mathrm{~m}$ of bioturbated siltstone to very finegrained sandstone with intercalations of ripplelaminated, fine- to medium-grained sandstone beds. Two marker beds are noteworthy: a hummocky sandstone bed $50 \mathrm{~m}$ above the base and a large-scale cross-bedded sandstone $200 \mathrm{~m}$ above the base. At the marker bed $200 \mathrm{~m}$ above base ammonites (Barroisiceras) and bivalves indicating a Coniacian age occur. Poorly preserved baculitid ammonites have also been recorded in the lower part.

Unit 7 consists of a c. $250 \mathrm{~m}$ thick, fine- to mediumgrained, uniform sandstone sequence with ill defined sedimentary structures. Indeterminable imprints after belemnites and baculitids are fairly common, while rare Lower Coniacian inoceramid bivalves at the base constitutes the youngest (pre-Quaternary) fossils so far determined from Kilen.

Unit 8 is about $550 \mathrm{~m}$ thick and consists of 6-7 upwards coarsening sequences of which only the lowest has been recorded in any detail. Each sequence is characterized by siltstone intercalated by fine-grained storm-sandstones in the lower parts, while the upper parts show a wide range of facies from siltstone to gravel. A very 
characteristic feature is the high frequency of large, very conspicuous Zoophycos. Except for poorly preserved bivalves no body fossils have been found. Accordingly the age is uncertain.

The Late Cretaceous sedimentation is dominated by a number of coarsening upwards sequences which - in general - become more coarse-grained towards the top. The deposition of black, silty mudstone follows a rapid deepening of the depositional basin, and within each sequence the slow increase in sand accumulation is associated with a gradual shallowing. This basic pattern was repeated several times in successive pulses of basin deepening. Frequently, the comparatively slow background mud deposition was interrupted by incoming conglomerate units containing redeposited phosphoritic and quartzite pebbles. The unusual occurrence of redeposited conglomerates in one of the sandy units (Unit 3) constitutes the most prominent marker bed of the entire sequence.

The geotectonic frame we suggest for the depositional evolution in the Late Cretaceous of Kilen is a pull-apart basin in an outer shelf environment. In this setting the first (Middle Turonian) black mudstone sequence corresponds to the initial depression, formed in the early phases of pull-apart basin formation (cf. Rodgers 1980); the isolated conglomerate beds represent sudden sediment influx related to earthquake activity and escarpment exposure along the strike-slip faults at the basin margins; while, finally, the repeated occurrence of mudstone units is related to the stepwise elongation and widening of the basin. Towards the end of deposition shallow marine conditions prevail as transtensional forces fade out.

\section{Early to Late Cretaceous in the outer part of Kilen}

The flat outer part of Kilen is composed of strongly deformed Mesozoic sediments, commonly visible through a very thin cover. However, actual exposures are restricted mainly to the two major rivers running close to the margins of the semi-nunatak.

The southern river complex was most intensively studied, and here an almost $10 \mathrm{~km}$ long and up to $3 \mathrm{~m}$ high section in a generally steeply inclined Cretaceous sequence is visible. Repetitions caused by folding and faulting within thick and rather uniform sequences make it difficult to evaluate the true thickness of the sediments present, and the values applied here may indeed be very conservative. However, it should be stressed that, despite obvious sedimentological similarities, none of the lithological units present in the inner part of Kilen were found in this area.

The overall pattern is that of a thick heterolithic fine-grained sandstone sequence totalling at least $650 \mathrm{~m}$, which is perhaps overlain by some 50 $m$ of clay shale. The alledgedly Middle Jurassic ammonites collected by the Greenarctic geologist in 1971 originated from this sandstone sequence. However, these ammonites were subsequently established to be of Middle Albian age (Birkelund \& Håkansson 1983). The clay shale, which may represent the top of the sequence in the outer part of Kilen, contains sideritic concretions with a dense, as yet undetermined fauna of Upper Cretaceous scaphitid ammonites and inoceramid bivalves.

The sandstone sequence contains 3 rather distinct facies types with gradual transitions. The basal part of the sequence is dominated by irregular, thin-bedded $(5-10 \mathrm{~cm})$ dark fine-grained sandstones, with minor shaly partings. Owing to bioturbation, no primary structures are visible. This rubbly facies occurs in sequences tens of metres thick, separated by thin (less than $1 \mathrm{~m}$ ) intervals of heterolithic sandstones with undisturbed primary sedimentary structures, such as parallel lamination and wave-ripple lamination. Wide channels with red, parallel laminated finegrained sandstone and a coquinoid basal layer occur at intervals. Recognizable trace fossils in the rubbly sandstones are of deep-water or euxinic types, such as Zoophycos and Chondrites.

Higher. (?) in the sequence this main facies gives way to a variety of thinly bedded heteroliths, with well preserved primary sedimentary structures, dominated by wave and current ripple-lamination, parallel lamination and low-angle to undulating parallel lamination. Trace fossils are restricted to surface trails, and occasional Zoophycos. The sandstone beds are separated by silty mudstones, with an overall sand/shale ratio approaching 1:1. At three levels, this facies gradually changes into pure, well bedded platy sandstones. Individual beds are thin with well pre- 


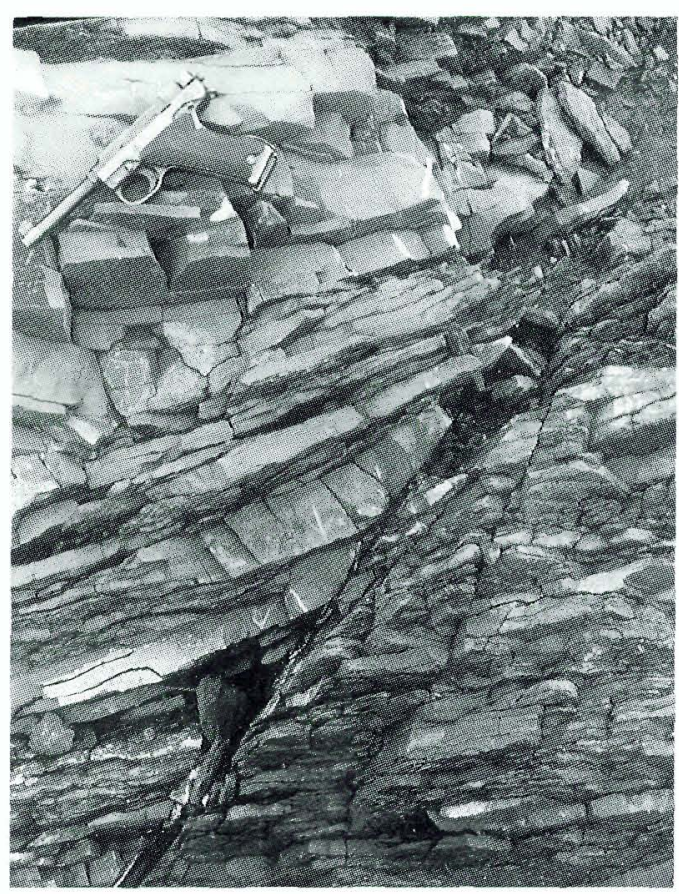

Fig. 4. Extensional fault in Lower Cretaceous sediments in the middle part of Kilen. The block to the left is downthrown.

served primary sedimentary structures of similar type. No large-scale cross-lamination was seen. Glauconitic sand as well as rare coarse-grained sandstone beds occur in this association. They may be graded, either normal or inversed, and exhibit well developed solemarks, such as flutecasts. Well developed slumping was observed within a single, pure sandstone unit.

Hummocky cross stratification is found at intervals throughout the sequence. The base of the hummocky beds is often erosive, typically with toolmarks, flute-casts and parallel striations. Each hummocky bed is rather thin (max. 1/2 m), representing only a single 'event' of formation with no amalgamation. Most of the hummocks are growing bed forms, while a few represent draping of sand over an erosive hummocky bottom topography.

The sedimentary environment is thus interpreted as a primarily low energy transition zone to shelf mud environment, characterized by a muddy background sedimentation. The large amount of fine-grained sand invariably present as thin beds is the result of frequent storm events, where fine-grained sand is brought across the transition zone to form lenticular and wavy bed- ded storm layers of considerable lateral extent within the otherwise muddy environment. The extreme uniformity in grain size (always finegrained sand) indicates a rather wide shelf. In this general setting alternations between heterolitic sandstone and dark rubbly sandstone reflect variations in bottom oxygen condition. The hummocky cross-bedded sandstones represent extreme cases of reworking, possibly owing to a combination of geostrophic currents and extreme storm waves (Swift et al. 1983). Such reworking leads to a resuspension of the silt, while the pure sand is redeposited as hummocks, terminated by parallel laminated sand and silt on the top as the finer material settles again. Oxygenation during reworking has led to an invariably light colour of the hummocky horizons.

The primarily growing bedforms of the hummocky beds indicate a distal shelf environment, as do the few normal and inversely graded coarse sand to gravel beds which may represent a proximal turbidite channel facies (Walker 1975).

\section{Structural geology}

The Wandel Hav Strike-Slip Mobile Belt is an important geotectonic element in the structural framework connecting the Atlantic and Arctic Oceans. The strike-slip belt extends from the northeastern part of Peary Land across Kim Fjelde, the Wandel Hav, and Kronprins Christian Land where Kilen occupies a central position (Håkansson \& Pedersen 1982). The width of the belt is at least $40 \mathrm{~km}$ and the known length is approximately $300 \mathrm{~km}$, but it has been speculated that it continues at least across the wide northeast Greenland shelf (Birkelund \& Håkansson 1983). The main displacement in the Cretaceous to earliest Tertiary development visible in Kilen is dextral, paralleling but predating the major off-set of the Svalbard block along the transform Spitzbergen Fracture Zone (Fig. 1).

The most conspicuous structures in Kilen are en échelon dome folds with axes trending roughly E-W (Håkansson et al. 1981b). Apparently, these folds were formed during later transpressional phases in the strike-slip belt, thus masking the geometry and the extent of structures related to earlier deformations along the belt. However, 


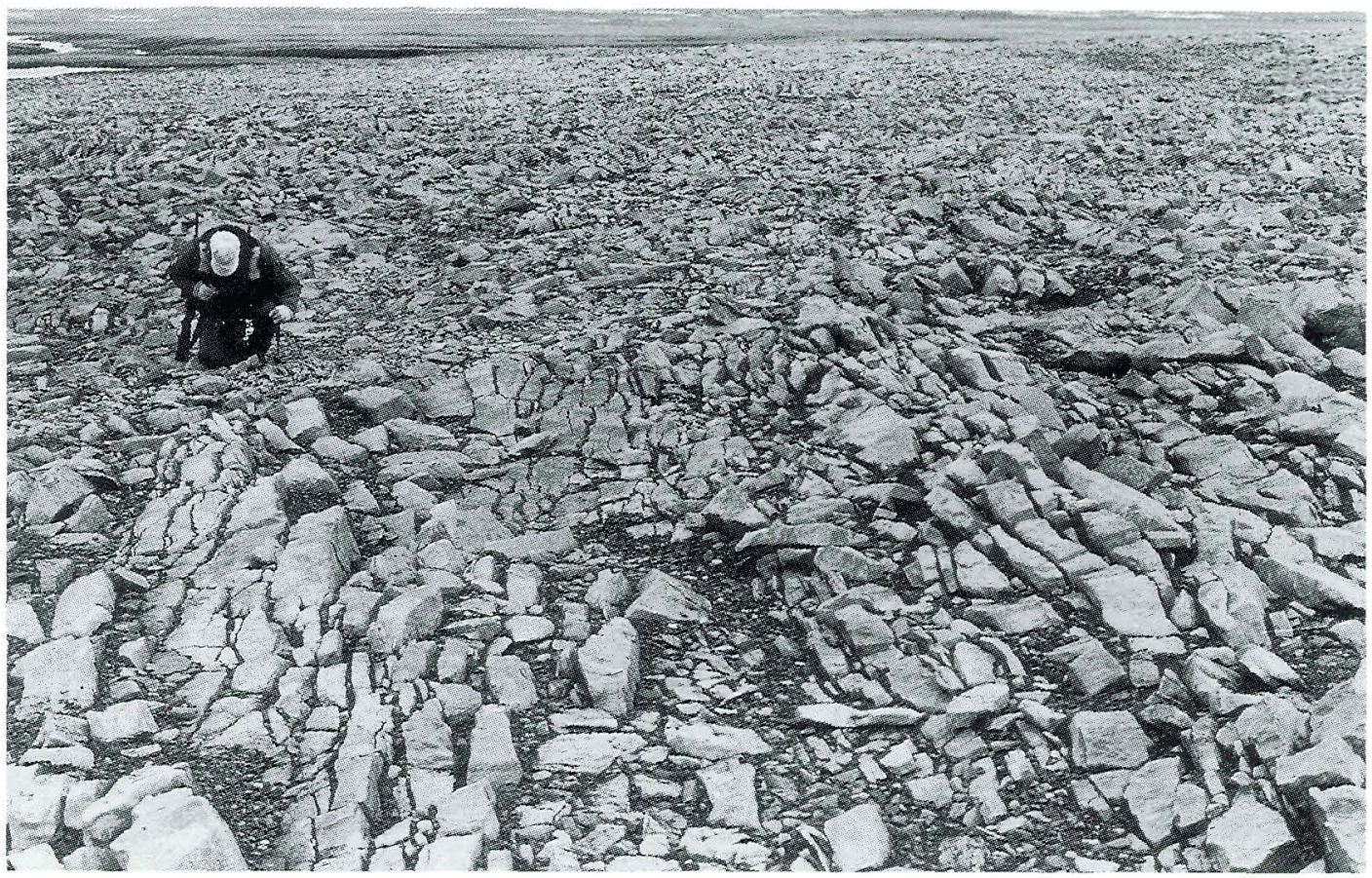

Fig. 5. Penetrative anastomosing jointing in the thick-bedded Lower Cretaceous unit $f$ sandstone, inner part of Kilen.

at least four distinct deformational phases can be discussed.

1) The earliest structural phase to be recognized in Kilen comprises a system of extensional normal listric faults (Fig. 4). Veins up to $20 \mathrm{~cm}$ in width containing calcite, ankerite and quartz are typically associated with the fault planes. The normal listric fault structures show meso-scale duplexes, which could suggest that the fault structures identified in Kilen are part of a larger extensional fault framework. Faults of this phase predate Upper Cretaceous sedimentation and are, therefore, regarded as an expression of the bedrock faulting resulting in the pull-apart basin development associated with the Late Cretaceous sedimentation (Håkansson \& Pedersen 1982; Birkelund \& Håkansson 1983). This extensional phase has been termed the Kilen Event (Pedersen 1988; Håkansson \& Stemmerik 1989).

2) Characteristic anastomosing penetrative shear jointing cuts through all stratigraphic units (Fig. 5). Depending on the lithology the geometry may vary, but the most marked difference is seen in the scale of spacing between joints, which seems to accord closely to bed thickness. The jointing is largely perpendicular to bedding and strikes dominantly ESE-WNW. An associated system of extensional planar joints is perpendicular to the shear joints and is commonly forming thin veins of calcite and quartz. The penetrative anastomosing joint system is tilted by dome folding, and it is therefore considered to be related to early transpressional shear forces prior to this folding

3) The conspicuous en échelon dome folding probably developed more or less simultaneously with the major faulting transecting the domes. However, since this faulting clearly displaces the domes laterally in subsequent events, the doming and faulting are considered to be separate phases. Dome size varies; the average size is $1 \times$ $2 \mathrm{~km}$, with a maximum amplitude of c. $100 \mathrm{~m}$. Maximum plunge of fold axes in the anticlinal domes is $10^{\circ}$, and along the sides of undisturbed domes bedding is tilted to about $45^{\circ}$. In crosssection these domes form upright anticlines with vertical axial planes (Fig. 6).

4) In the final phase of strike-slip faulting the faults separated the area into rhomb-shaped blocks. Displacement is estimated to be in the order of 1 to $5 \mathrm{~km}$. Minor dextral off-set of the domes within each block is in the order of $100 \mathrm{~m}$, while a second order sinistral faulting is abundant with off-sets around $5 \mathrm{~m}$. Two distinct macro- 


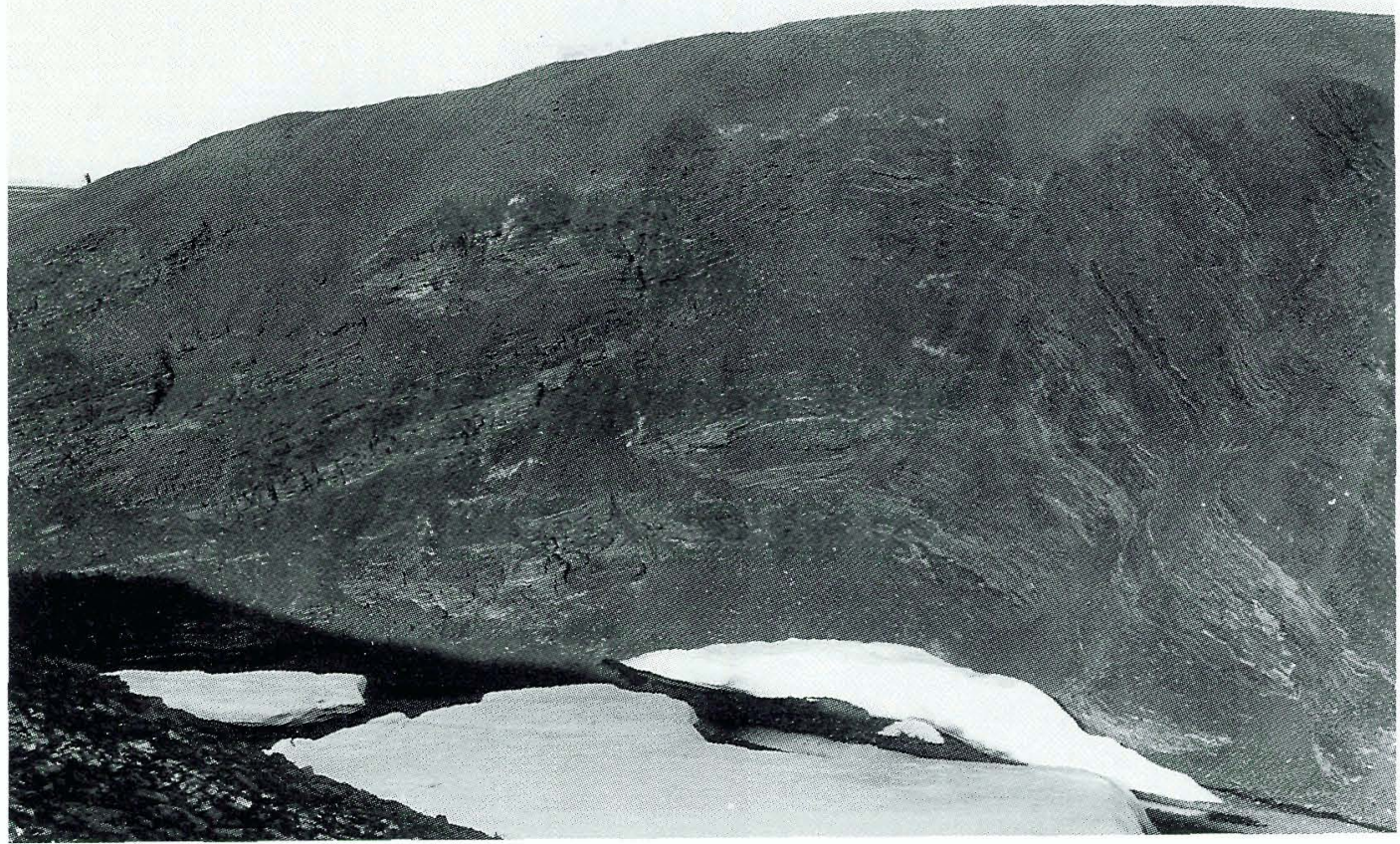

Fig. 6. Cross-section of dome anticline in sequence below the Upper Cretaceous sediments, inner part of Kilen. Note the person for scale on the hillside to the left.

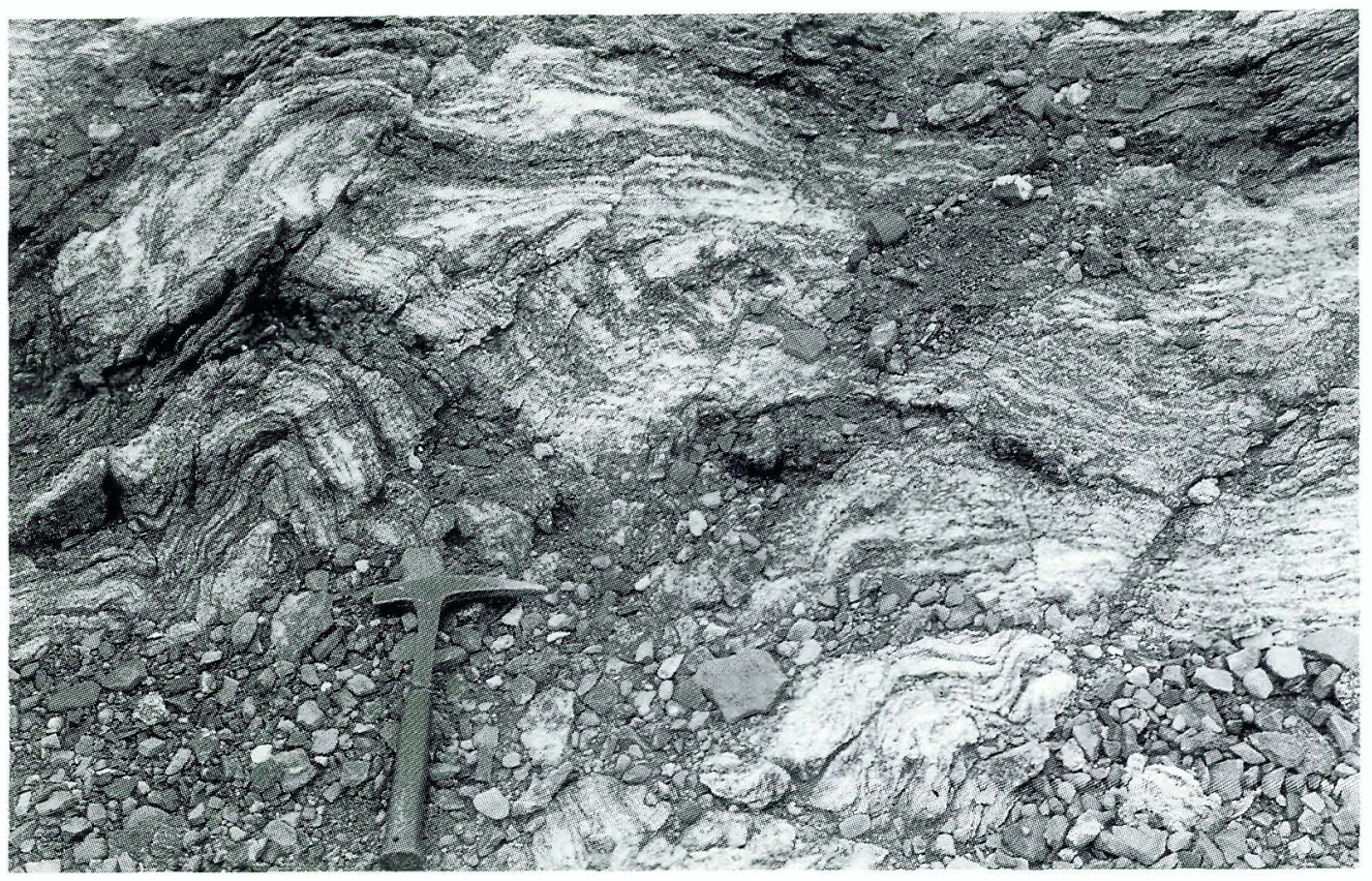

Fig. 7. Poly-deformed Upper Carboniferous gypsum (located at C in Fig. 1). 
scopic fault patterns have been recognized in the inner, best exposed part of Kilen; one is a parallel alignment of rhomb-shaped blocks dominating in the northeastern margin of the mountainous area, while the other pattern forms a splay zone bordering this area to the south. Typically, thrust faults are developed in the synclinal areas between the dome anticlines, and accordingly all thrust faults strike roughly E-W parallel to the axes of the domes. The geometry of the thrust fault surfaces is characteristic of strike-slip thrusting, i.e. steepening downwards and flattening towards the frontal part of the thrust sheet (cf. e.g. Lowell 1972). Phase $2-4$ has been included in the Kronprins Christan Land Orogeny (Pedersen 1988; Håkansson \& Stemmerik 1989).

\section{Poly-phased folding of Carboniferous evaporites}

A special structural feature was found in the southernmost extension of the mountanous area, where a severely deformed Carboniferous gypsiferous melange is exposed (fig. 7). Three phases of folding have affected the gypsum during its unconformable emplacement into the Lower Cretaceous sediments. The $F_{1}$ folding is an isoclinal recumbent folding with axes directed $100^{\circ}$ and plunge varying from $0^{\circ}$ to $50^{\circ}$ owing to superimposed folding. The $\mathrm{F}_{2}$ folding is more or less coaxial with $F_{1}$, but the folds are close to tight overturned to the north, with axial planes dipping moderately to the south. A thrust fault related to $F_{1}$ is folded by $F_{2}$. The folds related to $F_{3}$ are close upright folds with axes plunging $20^{\circ}$ to ENE. A number of interference patterns were identified, but it is likely that additional aberrant structures may be due simply to the unusually mobile nature of the deformed sediments.

The poly-deformed gypsum is regarded as a detached thrust wedge emplaced during the transpressional phase of the strike-slip system, i.e. the Kronprins Christian Land Orogeny, with part of the deformation possibly inherited from primary thermal convection.

\section{Quaternary geology}

The Pleistocene marine sequence found in 1980 (Hjort 1981) was reinvestigated and established as a separate unit, the Ymer Formation, belonging somewhere in the middle part of the Pleistocene. A whole array of radiometric and other dates are currently available; ${ }^{14} \mathrm{C}$ dating indicates an age in excess of 40,300 years (Håkansson 1982), Uranium/Thorium dating of shells indicates an age of at least $103 \mathrm{KA}$, thermoluminescence points to an age between 190 and 220 $\mathrm{KA}$, while amino acid analyses indicate that deposition took place prior to the Eemian interglacial (Hjort \& Feyling-Hanssen 1987). Together with the foraminiferal content, most notably the abundance of Islandiella inflata, this array of dates suggests that deposition of the Ymer Formation most likely took place during the Holsteinian interglacial period (Hjort \& Feyling-Hanssen 1987; Feyling-Hanssen 1990).

The sediments of the Ymer Formation have been found only around the lower c. $4 \mathrm{~km}$ of the main river running by the Sirius hut (Fig. 1), where they are apparently protected in depressions in the pre-Quaternary rocks. A total of $7 \mathrm{~m}$ have been recorded, with a general composition as outlined in Fig. 8. The sequence may be subdivided as follows.

A: silty diamicton of glacial or 'very proximal glacio-marine origin, with redeposited shell fragments.

B: silty diamicton of glacio-marine origin, containing Hiatella arctica, Mya truncata and Pecten groenlandicus in life position.

C: sandy, very stone-rich glacio-marine sediment of probably sublittoral origin, with several lag-horizons and extremely rich in shells. Both bivalves, gastropods and balanids occur in life positions. Species identified so far are Hiatella arctica, Mya truncata, Astarte borealis, Lepeta caeca and Balanus balanus. Some wood fragments were also found.

D: stratified sand with scattered ice-dropped stones and scattered bivalves and balanids in life position. Species are Hiatella arctica, Mya truncata, Astarte borealis, Serripes groenlandicus, Clinocardium ciliatum, Macoma calcarea, Portlandia arctica, Arca glacialis, Lepeta caeca and Balanus balanus. Wood fragments were also found here.

E: coarse glacio-fluvial deposits containing shell fragments; often with a strongly erosive base.

F: silty diamicton, with abundant dislocated 


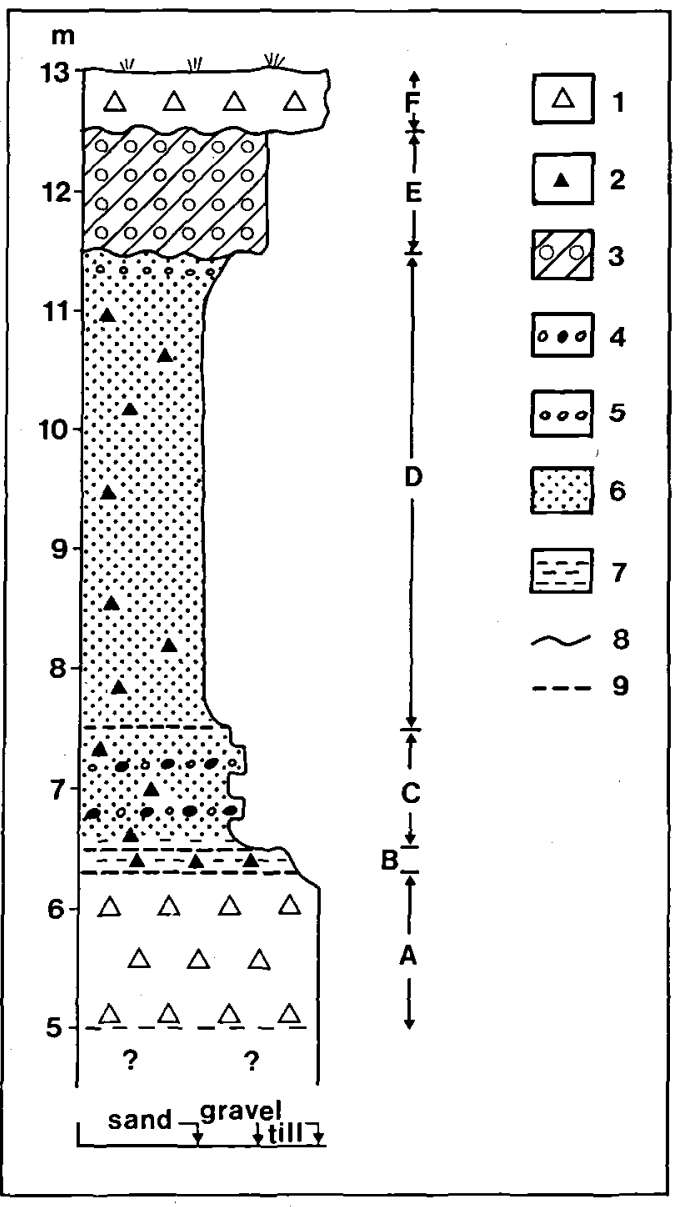

Fig. 8. Glacial and interglacial sedimentary sequence along the northern river (located at $Q$ in Fig. 1). Main stratigraphic units are indicated as A-F.

Legend: (1) till, (2) dropstones, (3) coarse glaciofluvial sediments, (4) stony-gravelly lag deposits, (5) gravel, (6) sand, (7) silt, (8) erosional contact between units, and (9) graded contact.

Hiatella arctica, Mya truncata and Astarte borealis.

The lower part of the sequence documents a seemingly gradual change from a sub-glacial to glacio-marine environment, which eventually reach a more fully marine, interglacial inner shelf environment with some icebergs still present. The fairly rich mollusc- and foraminiferal faunas indicate that conditions in this interglacial interval was probably somewhat above the present level at these high latitudes (Hjort \& FeylingHanssen 1987). Thus, the record of Macoma calcarea is the northernmost in eastern Greenland.

Then, heralded by glacio-fluvial erosion and deposition, followed a new glacial advance, and the dip of the glacio-fluvial sediments and glacially induced deformation of these beds show that this (Saalian?) ice advanced from NE - i.e. from the present shelf area. It is most unlikely that this over-riding ice deposited the top diamicton $(F)$, since the dislocated shells contained in this sediment have been ${ }^{14} \mathrm{C}$ dated to $7.830 \pm 80$ BP (Hjort \& Feyling-Hanssen 1987).

The distribution of crystalline, exotic erratics indicates that during the Weichselian Kilen was inundated by a major ice flow from the west, possibly an extension of the main Greenland Inland Ice. However, shell-bearing silts of latest Weichselian age $\left({ }^{14} \mathrm{C}^{\prime}\right.$ datings of $10,800 \pm 100 \mathrm{BP}$ and slightly younger; Hjort 1988) indicate that the southern and eastern part was ice-free by then. The prominent beach ridge complex on central Kilen was apparently sculptured in a preexsisting ridge composed entirely of till and glacio-fluvial deposits, and since beach ridges are lacking altogether north and west of the ridge, it is a likely indicator of a former ice margin.

The central ridge complex, as well as some of the earliest Holocene beach ridges at lower levels, have been cut off both to the north and to the south by subsequent advances of locally developed ice-caps. The main advance, which took place after c. 7,800 BP (cf. unit F above), created a shallow, ice-dammed lake behind the central ridge, while marine conditions prevailed on the lower part of the plain outside the ridge. A series of fairly indistinct moraines along the present margin of the northern icecap indicate that at least the northern margin later receded, perhaps in conjunction with the climatic aridification, which west of Flade Isblink caused the floral shift from Salix arctica heath to a true arctic polar desert around 3,500 BP (Funder 1986).

The "Little Ice Age" is reflected in a small advance of the ice front. ${ }^{14} \mathrm{C}$ dated plant remains from a recently exposed, totally barren 100-200 $\mathrm{m}$ wide zone along the northern ice margin show that it took place after c. $1680 \mathrm{AD}(270 \pm 50 \mathrm{BP}$; Hjort 1988).

Presently most of Kilen is still surrounded by the confluent ice domes of the Flade Isblink complex, which probably developed early in the Holocene. No signs of glacial erosion were found to be associated with the margins of these ice domes in Kilen, and the melt water emanating from the ice carries no suspended material. 


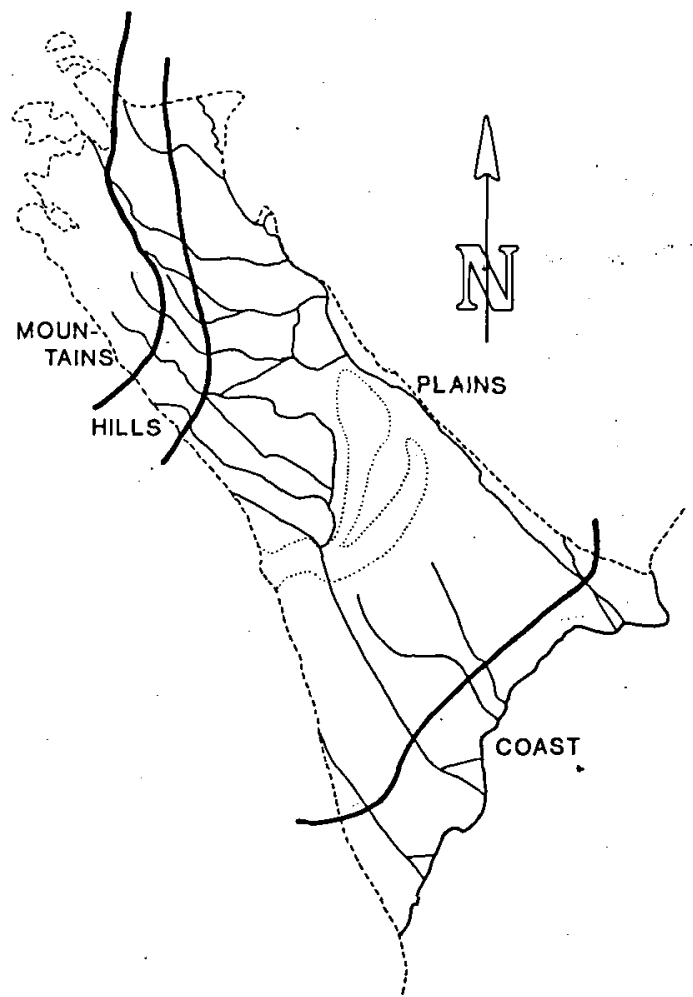

Fig. 9. Floristic/topographic regions of Kilen, (The central ridge complex is outlined).

As an ice-free area, Kilen is not the result of ice flow deflection caused by the interior mountains. These do indeed interfere with the easterly flow of ice from the thickest part of Flade Isblink, but ice from that dome does not reach much beyond these mountains. Towards NE and SW, Kilen is instead delimited by separate ice domes, of which the one to the north is the flattest. It appears that Flade Isblink consists of at least four such, semi-independent ice domes. Isotope data from a series of ice samples from one of these domes (Fig. 1) further indicate that they have accumulated under conditions corresponding closely to the present day climatic situation. Thus the average $\delta\left({ }^{18} \mathrm{O}\right)$ value of $c .-19.5 \%$ is very close to the yearly mean at Station Nord $(-17 \%)$ when the difference in altitude is considered (data courtesy N.Reeh, GGU).

It therefore appears that the glaciers in northern Kronprins Christian Land are more extensive, although much thinner, today than during the peak of the Weichselian, or during the Late Weichselian - Early Holocene deglaciation pe- riod, and that they had their maximum extent during the advance sometime after $7,800 \mathrm{BP}$. This local and unusual Holocene glaciation pattern is considered to be the combined result of 1 ) interglacial precipitation-bearing cyclonal patterns, 2) locally derived precipitation from the Nord $ø$ stvandet Polynya (which may itself be an interglacial feature), and 3) the existence of a very cold atmospheric boundary layer retarding ablation from sea level and a few hundred meters upwards (Hjort 1988).

\section{Biological investigations}

A number of biological projects centered around birds and higher plants were carried out in Kilen. Vegetation was of low diversity and low general density (usually below $1 \%$ ground cover), but the abundance of birds was exceptional for North Greenland (cf. Håkansson et al. 1981a). A total of 34 species of higher plants and 29 species of birds have been recorded during our visits to Kilen, some considerably beyond the limits of their previously know ranges. Sea mammals were rather plentiful, but land mammals appear unusually scarce.

\section{Plants}

During the short visits in 1980 a total of 25 species of flowering plants was registered, mainly from the elevated area in the inner part of Kilen. The 1985 expedition added another 9 species, giving a total of 34 species of vascular plants (Table 1).

Compared to more extensively vegetated, larger land areas to the south and west (i.e. Amdrup Land and Holm Land, and Peary Land, respectively), the vegetation at Kilen is remarkable in the following ways: 1) Cyperaceous plant species of the genera Carex and Eriophorum, which are otherwise abundant in northern and eastern Greenland, are totally absent; 2 ) woody plants, e.g. dwarf shrubs such as Dryas, Cassiope, Vaccinuum, etc., are missing apart from one isolated, small population of non-flowering Salix arctica. In both characterstics the Kilen vegetation resembles that of Danskøya in northwestern Svalbard (de Neergaard 1985) and, to some extent, also the other small nunataks fringing the northern half of Flade Isblink. As a general fea- 
Table 1. Distribution of vascular plants in four floristic regions of Kilen with information on phenological stages.

\begin{tabular}{|c|c|c|c|c|c|c|c|c|c|}
\hline \multirow[t]{2}{*}{ Species } & \multicolumn{4}{|c|}{ Floristic region } & \multicolumn{5}{|c|}{ Phenologya } \\
\hline & Coast & Plain & Hills & Mountains & $S$ & $V$ & $\mathbf{B}$ & $F$ & $R$ \\
\hline Draba adamsil & $A^{b}$ & $A$ & A & A & & + & + & + & \\
\hline D. subcapitata & $A$ & $A$ & $A$ & $A$ & & + & + & + & \\
\hline Papaver radicatum & $A$ & $A$ & $A$ & $A$ & + & + & + & + & \\
\hline Poa abbreviata & A & $A$ & A & A & + & + & + & + & \\
\hline Saxifraga caesp/tosa & A & A & A & A & & + & + & + & \\
\hline S. cernua & A & $A$ & A & $A$ & & + & + & & + \\
\hline S. oppositifolia & A & $A$ & A & A & + & + & + & + & \\
\hline Stellaria longipes & $A$ & A & A & $A$ & & + & & & + \\
\hline Cochlearia groenlandica & $A$ & $A$ & A & $A$ & + & + & + & + & \\
\hline Cerastium regelli & A & $A$ & A & $A$ & & + & & & + \\
\hline C. arcticum & R & A & A & A & & + & + & + & \\
\hline Alopecurus alplnus & $\mathrm{R}$ & $A$ & A & $R$ & & + & + & + & $(+)$ \\
\hline Potentilla hyparctica & $\mathbf{R}$ & $A$ & A & $\mathrm{R}$ & & + & + & + & \\
\hline Saxifraga tenuis . & $\mathrm{R}$ & A & A & R & & + & + & + & \\
\hline S.nivalls & $L$ & A & $A$ & A & & + & + & + & \\
\hline Luzula confusa & $L$ & A & A & $R$ & & + & + & + & \\
\hline Phippsla algida & A & A & $\mathbf{R}$ & A & + & + & + & + & \\
\hline Puccinellia angustata & $A$ & A & $L$ & R & & + & + & + & \\
\hline Cardamine bellidlfolla & 1 & $\mathbf{R}$ & $\mathbf{R}$ & A & + & + & + & + & \\
\hline Saxifraga hyperborea & $L$ & $\mathbf{L}$ & $L$ & A & & + & + & + & \\
\hline Poa arctica & $L$ & $L$ & $L$ & $L$ & & + & + & + & $(+)$ \\
\hline S. flagellaris & - & $R$ & $A$ & $R$. & & + & + & + & + \\
\hline Luzula arctica & - & $L$ & $\dot{L}$ & $\mathrm{R}$ & & + & + & + & \\
\hline Minuartia rubella & - & $\bar{L}$ & $\bar{A}$ & $\mathrm{R}$ & $(+)$ & + & + & + & \\
\hline Festuca hyperborea & - & R & $R$ & $L$ & & + & + & + & \\
\hline Braya thorild-wulffil & - & $L$ & $L$ & - & & + & + & + & \\
\hline Ranunculus sulphureus & - & $\mathbf{R}$ & R & - & + & + & + & + & \\
\hline Potentilla rubricaulls & - & A & $\mathrm{A}$ & - & & + & + & + & \\
\hline Juncus biglumis & - & - & $L$ & - & & + & + & + & \\
\hline Sallx arctica & - & - & $L$ & - & & + & & & \\
\hline Taraxacum arcticum & - & - & $L$ & - & + & + & + & + & \\
\hline Draba belliI & - & - & R & $L$ & . & + & & & \\
\hline Poa colpodea: & - & - & - & L & & + & & & + \\
\hline Ranunculus sablnel & - & $\mathbf{R}$ & - & - & & + & + & + & \\
\hline Total 34 & 21 & 28 & 32 & 27 & 9 & 34 & 29 & 28 & 7 \\
\hline
\end{tabular}

a) S. seedlings present

$V$ - vegetative plant without flowers

B - flowering plant

$F=$ plant with mature fruits

A. vegetative reproduction b) A - abundant

$R=$ spars $\theta$

L- locah le. one or two sites ture, the vegetation of these smaller land areas is low in species with diaspores and seeds customarily associated with wind dispersal, whereas there is an overall dominance of species with small, round seeds as for instance Saxifraga spp., Cerastium spp., and Papaver radicatum.
The distribution of plants within Kilen shows four well defined floristic regions in close association with the general topography (Fig. 9). Most plant species are met with in all four regions, although their relative importance varies.

The coastal region supports the most sparse 
Table 2. Distribution of vascular plants in three vegetation zones on the slope of the raised beach ridge at $65 \mathrm{~m}$ elevation, central Kilen, August $14 \mathrm{th}$. Plot size: 10 circles of $0.1 \mathrm{~m}^{2}$.

\begin{tabular}{|c|c|c|c|c|c|c|c|c|c|}
\hline \multirow[b]{2}{*}{ Zone } & \multicolumn{3}{|c|}{ Frequency } & \multicolumn{3}{|c|}{ Cover, plants $/ \mathrm{m}^{2}$} & \multicolumn{3}{|c|}{ Phenology } \\
\hline & Upper & Middle & Lower & Upper & Middio & Lower & Upper & Middle & Lower \\
\hline Alopecurus alpinus & 50 & 100 & 100 & 5.0 & 318.6 & 25.8 & $F$ & $F$ & $y$ \\
\hline Papaver radicatum & 50 & 70 & 40 & 0.7 & 12.9 & 0.6 & $C-V$ & B & (F) \\
\hline Stellaria longipes & 10 & 85 & 40 & 2.0 & 2.6 & 1.6 & $F$ & V & v \\
\hline Ranunulus sabinel & 10 & 70 & 20 & 0.1 & 1.3 & 0.2 & V & $C-F$ & $v$ \\
\hline Poa abbrevlata & 70 & 15 & 20 & 1.2 & 0.4 & 0.5 & $F-M$ & V & v \\
\hline Orabe adamsI" & 20 & 15 & 20 & 0.4 & 0.1 & 0.3 & $v$ & $v$ & M \\
\hline Draba subcapitata & 40 & 30 & 10 & 1.0 & 0.3 & 0.1 & $C-F$ & v & v \\
\hline Cardamine bellidifolla & 30 & 30 & 20 & 0.6 & 0.3 & + & $C-M$ & $\mathbf{F}$ & v \\
\hline Saxifraga cernua & 50 & 70 & 20 & 1.3 & 0.7 & 0.2 & B & B & v \\
\hline Saxifraga tenu's & - & 30 & - & - & 0.3 & - & - & B & - \\
\hline Saxifraga nivalis & - & 30 & - & + & 0.3 & . & (F) & B & (F) \\
\hline Saxifraga caespitosa & - & 15 & - & * & 1.4 & - & V & V & - \\
\hline Cochlearla groonlandica & - & 70 & - & - & 3.3 & - & $\cdot$ & $\mathrm{C}-\mathrm{M}$ & - \\
\hline Phippsla aloida & - & 10 & - & - & 0.1 & - & - & V & - \\
\hline Cerastium arcticum & 10 & - & 10 & 0.1 & - & 0.1 & $F$ & - & (F) \\
\hline Cerastium regelll & - & - & - & - & • & - & - & V & - \\
\hline Potentilla hyparctica & - & - & - & • & - & - & $V$ & - & - \\
\hline Saxifraga hyperborea & - & - & - & - & + & - & - & v & - \\
\hline
\end{tabular}

a) The three analyses were located on the inland side of rldge, $20 \mathrm{~m}$ apart with 2-3 $\mathrm{m}$ difference in elevation. b) $C$, colyledons present; $V$, vegetatlve plant; $B$, buds present: $F$, flowers present; $M_{4}$ mature seeds.

vegetation and the lowest number of species (Table 1), and only 21 out of the 34 species were recorded here. A continuous plant cover was seen only locally, and then it was mostly associated with raised beach ridges with the most dense vegetation on the slopes of either side of the ridge. The area around the Sirius hut, in particular, was found to be fertile, most likely reflecting the unusually high concentration of sea birds nesting here with easy access to the food supply of the delta. It should be noted in this connection that human activities have not (yet) influenced this pattern, since the hut was not constructed until 1979.

The most abundant plant species - as everywhere in Kilen - is Papaver radicatum (see below). It is present in all plant communities and occurs frequently as isolated individuals. Only where the soil moisture is too high the dominance is passed on to Cerastium regelii.

The plains. This floristic region is delimited from the coastal area by the very prominent set of beach ridges between 22 and $19 \mathrm{~m}$. It ranges to the foothills in inner Kilen, where the limit ap- proximately follows the $100 \mathrm{~m}$ contour, and the region thus covers most of Kilen. Apart from the slightly elevated central ridge complex around 65 $m$ (outlined in Fig. 9), the plains are exceedingly flat. Although most of the region is vegetated, the density is extremely low apart from ice wedge polygons and the lee side of boulders and stones, where a dense plant cover may occur in small, restricted areas.

Ranunculus sabine $i$ is found only on the plains, where it grows preferentially in polygon cracks in the central area. However, the most characteristic species of the plains is Alopecurus alpinus, which in wet and mesic places has an unusually high shoot density (Table 2). It is distributed throughout the plains, occurring in polygon ditches as well as in the troughs within the polygons, and in the dense vegetation on the lee side of stones and boulders. Together with Papaver radicatum it constitutes the main diet of the large population of Brent Goose on the plains (Fig. 10; Hjort et al. 1987).

Analyses of gradients across three adjacent zones within a plant community from the central 
beach ridge complex show that the distributional pattern of plant species on the plains is controlled by very modest variation in abiotic factors such as soil moisture and snow cover (Table 2). The high shoot density and species diversity in the middle zone is taken to indicate that vegetation is restricted by prolonged snow cover in the low areas, whereas desiccation may be the restricting factor in the slightly higher, more exposed areas. This pattern is most clearly demonstrated by the two dominant species $A$. alpinus and $P$. radicatum.

The hili region has the most varied topography and probably the least harsh climate of the entire semi-nunatak. The widest variation in plant cover was seen here, together with the highest diversity and the highest productivity of the plants. Only two species, Ranunculus sabinei and Poa colpodea were not seen in this region, ocurring otherwise on plains and mountains respectively.

Three plant species were found only in the hill region: Juncus biglumis, Salix arctica, and Taraxacum arcticum. All three species occur only in small, isolated populations, and the latter two are the only species with seeds and fruits designed for wind dispersal seen in Kilen.

The mountains. This region roughly includes all areas above $200 \mathrm{~m}$, with $505 \mathrm{~m}$ as the maximum altitude. Broadly speeking, the vegetation cover decreases with increasing altitude, showing the highest diversity and coverage in snowpatch communities, where Saxifraga flagellaris, Cerastium arcticum, Cochlearia groenlandica, Phippsia algida, and several other species are abundant.

\section{Floristic relations}

Within recent years a number of classification systems related to the biogeography and temperature requirements of Arctic floras have been proposed from most Arctic regions (Edlund 1983; Rannie 1986; Aleksandrova 1988; Elvebakk 1990). It is therefore tempting to test their performance with respect to a flora as extreme as the one recorded in Kilen.

All the floristic regions of Kilen can be referred to the arctic polar desert zone as delimited by Aleksandrova (1988), corresponding also to the outer coast district of Bay (1992). One of the characteristics of the Sibirian arctic polar desert is the complete absence of dwarf shrubs, a condi- tion that - apart from a very restricted occurrence of Salix arctica - applies to the whole area of Kilen.

Elvebakk's 'Index of Thermophily' as a method for defining local vegetation/biogeographical zones (Elvebakk 1990) is based on the climatic requirements of 58 flowering plants (and 11 cryptogams) selected for their varying degree of thermophily. Of the 58 'thermophilous' species used by Elvebakk only one is present at Kilen, i.e Taraxacum arcticum - registered at a single, protected locality in the Hill Region. As a consequence Kilen is classified as arctic polar desert in complete accord with the classification of Aleksandrova (1988).

When compared to the vegetation zonation in the Canadian Arctic established by Edlund (1983), Kilen classify very closely with the most impoverished high arctic floral zone (Zone 1 of Edlund 1983). Total plant cover is here as low as $1-5 \%$, less than 35 species are present, and dominant are species with isolated growth like Saxifraga oppositifolia, Luzula spp., Alopecurus alpinus and Puccinellia together with Papaver.

The near total lack of dwarf shrubs in Kilen (apart from the single Salix population) places the flora outside the 'miniforest zone' as defined in the high arctic of Canada. Here the 'minitreeline' coincides with a mean daily July temperature of $3-3.5^{\circ} \mathrm{C}$, whereas the limit of plant growth is as low as $2.5^{\circ} \mathrm{C}$ (Edlund 1983). Hence, mean daily July temperature on the lowland of Kilen may be between 2.5 and $3.0^{\circ} \mathrm{C}$, and in the Hill region around $3.5^{\circ}$ but not as high as $4.0^{\circ} \mathrm{C}$ which is the supposed limit for the 'mini-forest zone' with widespread occurrence of dwarfshrub heathland.

From a somewhat different approach Rannie (1986) has found an even higher correlation between the number of vascular plant species present and summer air temperature in the high arctic of Canada. When applying the "Ranniecorrelation" to our data from the vegetation zones of Kilen we estimate the July means for the four regions to be $2.3-2.6^{\circ} \mathrm{C}, 2.5-2.9^{\circ} \mathrm{C}, 2.7-$ $3.0^{\circ} \mathrm{C}$, and $2.5-2.8^{\circ} \mathrm{C}$ for coast, plain, hills and mountains, respectively. These figures support. the estimates based on the "mini tree-line" as" outlined by Edlund (1983). 
Table 3. Papaver radicatum petal colour distribution in relation to altitude in North Greenland.

\begin{tabular}{|c|c|c|c|c|}
\hline Locality & Topography & $\begin{array}{c}\text { Altitude above } \\
\text { sealevel, } m\end{array}$ & $\begin{array}{l}\text { Yellow } \\
\text { petals }\end{array}$ & $\begin{array}{l}\text { No. of } \\
\text { plants }\end{array}$ \\
\hline Kilen & Beach ridge & 9 & + & $>100$ \\
\hline Kilen & Beach ridge & 15 & 2 & 420 \\
\hline Kilen & Plain $^{a}$ & 65 & 54 & 100 \\
\hline Kilen & Slope & 100 & 63 & 86 \\
\hline Kilen & Slope & 165 & 55 & 112 \\
\hline Station Nord & Plain ${ }^{b}$ & 10 & 17 & 100 \\
\hline Thule & Plain $^{c}$ & 20 & 55 & 100 \\
\hline Thule & Slope & 200 & 89 & 100 \\
\hline
\end{tabular}

Elevated beach ridge, gray, eroded sandstone with silt.

b $10^{\circ}$ east-facing slope, grayish-yellow eroded sandstone.

c Eroded black shale, $5^{\circ}$ south-facing slope.

$+=$ Yellow-flowered plants present, but much less then $1 \%$.

\section{Papaver radicatum}

The population structure and color polymorphism of the Arctic Poppy was the target of particular investigations, in part reflecting the fact that this is by far the most conspicuous species in all regions of Kilen.

Flower colour polymorphism. Two flower colour morphs were encountered; along with the well-known type with bright yellow petals a clearly destinguishable phenotype with white to whitish petals was widespread (Mølgaard 1989). The white flowered poppy was most common in the Coastal- and Plain Zones, whereas the one with yellow flowers dominated the Hill and Mountain Zones (Table 3). Yellow petals have been found to be more efficiant in reflecting the solar radiation and, thus, secure a higher temperature around the developing seeds than in flowers with white petals (Table 4). Yellow poppies, therefore, should be expected to dominate whenever the sun is reliable, and in total agreement with their relative abundance, this condition seems to be fullfilled only in the inner part of Kilen. Thus eleven days in the peak of the growing season (late July - early August) provided a mere total of five hours of sunshine in the coastal region (as short breaks in an otherwise near constant haze or mist under overcast conditions) while, during the very same period, sunshine was recorded daily for at least some hours in the hills and mountains.

It appears, therefore, that in regions where sunshine probability is high, there may be an advantage in spending the extra energy to synthesize the yellow colour agent, whereas the white phenotype, spending less energy on flower colour, will be of advantage as soon as sunshine probability is reduced (Mølgaard 1989). The general superiority of yellow flowers in the attraction

Table 4. The influence of petal colour on temperature levels in various parts of Papaver radicatum plants with white and yellow flowers, Kilen 1985.

\begin{tabular}{lccccc}
\hline No. observations & Leaves & Petals & Stigma & Ovary & Temp-range \\
\hline $\begin{array}{l}\text { Yellow petals 6 } \\
\text { White petals 7 }\end{array}$ & $14.3 \pm 1.4$ & $13.3 \pm 1.0$ & $16.5 \pm 1.8$ & $18.8 \pm 2.0$ & $5.5 \pm 2.2$ \\
$\begin{array}{l}\text { Temp-difference } \\
\text { between yellow \& white }\end{array}$ & $14.2 \pm 1.9$ & $12.4 \pm 1.3$ & $14.8 \pm 2.1$ & $17.4 \pm 2.1$ & $5.1 \pm 1.4$ \\
t-test & 0.1 & 0.9 & 1.7 & 1.4 & 0.4 \\
& 1.67 & $2.43^{*}$ & $2.1 \hat{*}$ & 1.91 & 1.08 \\
\hline
\end{tabular}


Table 5. Relative phenological distribution of populations of Papaver radicatum from the 4 floristic regions of Kilen. The offspring swarm is representative for a recently established population in the coastal region.

\begin{tabular}{|c|c|c|c|c|c|c|c|c|c|c|c|c|c|c|c|c|c|}
\hline \multirow[b]{2}{*}{ Region } & \multirow{2}{*}{$\begin{array}{l}\text { Number } \\
\text { of } \\
\text { populations }\end{array}$} & \multicolumn{2}{|c|}{$\begin{array}{c}\text { Seedlling } \\
\text { stage }\end{array}$} & \multirow[b]{2}{*}{1} & \multirow[b]{2}{*}{2} & \multirow[b]{2}{*}{3} & \multicolumn{4}{|c|}{ Number of shoots } & \multirow[b]{2}{*}{8} & \multirow[b]{2}{*}{9} & \multirow[b]{2}{*}{10} & \multirow[b]{2}{*}{$>10$} & \multirow[b]{2}{*}{ Total } & \multicolumn{2}{|c|}{$\begin{array}{c}x^{2} \\
\text { Offspring swarm }\end{array}$} \\
\hline & & 1 & 2 & & & & 4 & 5 & 6 & 7 & & & & & & & \\
\hline $\begin{array}{l}\text { Offspring } \\
\text { swarm }\end{array}$ & $1 \cdots$ & 13 & 26 & 32 & $\cdots 12$ & $3 \cdots$ & 3 & 4. & 5 & $\therefore$ & 1 & 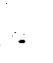 & - & - & 89 & 180.7 & \\
\hline Coast & 9 & 6 & 5 & 36 & 20 & 8 & 5 & 3 & 3 & 3 & 1 & 1 & 1 & 6 & 99 & 139.5 & 18.8 \\
\hline Plains & 6 & 1 & 5 & 38 & 17 & 10 & 5 & 5 & 3 & 3 & 2 & 1 & 2 & 8 & 100 & 35.2 & 22.2 \\
\hline Hills & 4 & 4 & 6 & 38 & 26 & 9 & $\theta$ & 4 & 2 & 1 & 1 & - & - & - & 100 & 26.9 & $26 \overline{6} .9$ \\
\hline Mountains & $s \quad 6$ & 2 & 3 & 37 & 20 & 12 & 7 & 8 & 3 & 1 & 1 & 2 & 1 & 3 & 100 & 33.1 & 18.7 \\
\hline$x^{2}($ off st & sw.) & 5.7. & $\begin{array}{l}* * * * \\
128.8\end{array}$ & 1.7 & 15.3 & 12,3 & 8.3 & 9.7 & 3.8 & $\ddot{9.9}$ & 3.5 & 6.7 & 7.4 & 34.1 & & & \\
\hline$x^{2}(-$ off.st & & $\begin{array}{l}* * * * \\
18.9\end{array}$ & 3.5 & 0.3 & 6.1 & 2.8 & 5.3 & 9.2 & 1.7 & 5.5 & 3.0 & 3.4 & 5.2 & 21.7 & & & \\
\hline
\end{tabular}

$*^{* * *}, * *$ indicale the level of significance in the $x^{2}$-analyses: $P<0.5, P<0.1$ and $P<0.01$, respectively.

of pollinators (Kevan 1972) may be of limited relevance in Kilen, since pollinating insects are rare and selfpollination probably customary; more likely the 'showy' appearance of the yellow phenotype has turned disadvantageous due to the high feeding pressure from the abundant geese in most of the low-land areas (see below).

Population Structure. Papaver populations were scored for the frequency of life stages defined as the number of apical shoots in the ro-

Table 6. Phenology and reproduction of Papaver radicatum at three localities of increasing population maturity in the plains region near the southern icccap at central Kilen. Elevation $75 \mathrm{~m}$, August 13th.

\begin{tabular}{|c|c|c|c|c|c|c|c|c|c|c|c|c|c|c|c|c|}
\hline \multirow[b]{2}{*}{ Locality } & \multirow[b]{2}{*}{ No. } & \multirow{2}{*}{$\begin{array}{c}\text { Distance } \\
\text { to } \\
\text { glacier, m }\end{array}$} & \multicolumn{2}{|c|}{$\begin{array}{c}\text { Seedling } \\
\text { stage }\end{array}$} & \multirow[b]{2}{*}{1} & \multirow[b]{2}{*}{2} & \multirow[b]{2}{*}{3} & \multirow[b]{2}{*}{4} & \multicolumn{3}{|c|}{ Number of shoots } & \multirow[b]{2}{*}{8} & \multirow[b]{2}{*}{$\theta$} & \multirow[b]{2}{*}{10} & \multirow[b]{2}{*}{$>10$} & \multirow[b]{2}{*}{ Total } \\
\hline & & & 1 & 2 & & & & & 5 & 6 & 7 & & & & & \\
\hline Young eolean slope & 24 & 400 & 1 & 5 & 37 & 14 & 3 & - & - & - & - & .1 & - & - & 6 & 67. \\
\hline Cryoplanation terrace & 23 & 300 & - & 1 & 35 & 17 & 12 & 8 & 12 & 4 & 3 & 5 & - & - & 5 & 102 \\
\hline Old terrace near ice & 22 & 50 & - & - & $\begin{array}{l}1 \\
-\end{array}$ & $\frac{1}{-}$ & $\frac{1}{-}$ & $\frac{1}{-}$ & - & 1 & 2 & 1 & $\frac{1}{-}$ & 4 & 17 & - \\
\hline Total & & & 1 & 6 & 73 & 32 & 16 & 9 & 12 & 5 & 5 & 7 & 1 & 4 & 28 & 199 \\
\hline \multirow[t]{3}{*}{ Percentage } & 24 & & 1 & 7 & 55 & 21 & 4 & - & - & $\cdot$ & - & 1 & - & - & 9 & 98 \\
\hline & 23 & & - & 1 & 34 & 17 & 12 & 8 & 12 & 4 & 3 & 5 & - & - & 5 & 101 \\
\hline & 22 & & - & - & 3 & 3 & 3 & 3 & - & 3 & 7 & 3 & 3 & 13 & 57 & 98 . \\
\hline \multicolumn{17}{|l|}{ Reproduction } \\
\hline \multirow[t]{3}{*}{ Flowers/plants } & 24 & & & & & $v_{1}$ & - & - & - & - & - & $\therefore$ & - & - & $1 / 1$ & $2 / 2$ \\
\hline & 23 & & & & & $1 / 1$ & $2 / 1$ & $1 / 1$ & $2 / 2$ & - & - & $5 / 4$ & - & - & - & $11 / 9$ \\
\hline & 22 & & & & & - & - & - & - & - & $1 / 1$ & $3 / 1$ & $3 / 1$ & $1 / 1$ & $6 / 1$ & $14 / 5$ \\
\hline
\end{tabular}


sette. The frequency composition varied between populations to a much higher degree between regions than within regions; however, local variation was pronounced (Table $5 \& 6$ ).

A high number of seedlings and juvenile plants may be indicative of a dynamic vegetation under establishment, whereas a low number of seedlings and a high number of polyapical rosettes would characterize a senescent population in a mature community at late successional stage. At this stage a high intensity of flowering may occur with subsequent seed production and seed dispersal; however, germination and establishment is low. Establishment is always in bare soil without moss cover, whereas senescent plants may be overwhelmed by invading mosses, which grow up beneath the shoots. This is similar to observations with $P$. polare in Franz Josef Land (Aleksandrova 1988).

The general pattern in the distribution of $\mathrm{Pa}$ paver populations is shown in Table 5. Behind the mean values for the regions are of course a variation, although not as wide as that shown in Table 6 for the plain region. By far the most dynamic populations are found in the hill region with a high number of seedlings in combination with the absence of large rosette plants. The coastal area has a high number of seedlings as an indication of ongoing germination and establishment. In this respect it differs from the plains, although both of these regions have a high number of old plants indicating an ancient establishment. The mountain region is intermediate in both respects, probably due to local variation in stability of the plant community and a more varied time lapse since colonization. As seen from the statistics most attention should be paid to the relative amounts of seedlings and of the very large plants, when using Papaver population composition as a measure for age and stability of the plant community under consideration.

\section{Mammals}

Although both Ringed seal Phoca hispida and Bearded seal Erignathus barbatus were observed along the coast, the most characteristic feature was the presence of Walrus Odobenus rosmarus. They were regularly seen in small numbers (the highest daily total being 8 ), and at least one female with young was present.
Although these observations constitute the northernmost record of this species thus far, they are in complete accord with our previous observations further south in the Nordøstvandet Polynya. Thus, in 1980 heards of Walruses were accountered in the coastal ice from Mallemuk Fjeld in the south to Antarctic Bugt (just south of Kilen) in the north. The highest concentration was found in the ice along the east coast of Amdrup Land, and here more than 100 Walruses were recorded in largely stationary heards of 4 to 14 animals (Aug. 1980). Virtually all groups included calves, and it is evident that the Walrus population discovered by the Danmark Expedition 1906-08 and encountered also by the Danish Northeast Greenland Expedition 1938-39 (Pedersen 1942), is viable and well established in this polynya.

Two Bowhead whales Balaena mysticetus were seen on August 8. They spent some hours diving and swimming around about $2 \mathrm{~km}$ off the Sirius hut - in good light so that all characteristic features could be noted. This observation and three animals seen by John Andersen 1984 (Pers. comm.), and perhaps also one unidentified, large whale seen here during the Ymer-expedition 1980, shows that the East Greenland population of this species is not yet entirely extinct.

Several tracks of Polar bears Ursus maritimus were seen, even in the interior mountains, but no animals were encountered during the stay at $\mathrm{Ki}$ len. However, there can be little doubt that the Polar bear is common around the Nordøstvandet Polynya. Not only have previous expeditions (travelling on the sea ice in early spring and early winter) reported frequent encounters, but in 1980 our sightings of 5 adults and 3 cubs (in 2 litters) during a single helicopter flight over the ice between Amdrup Land and Henrik Krøyer Holme (ultimo June) established beyond doubt the presence of a fair sized breeding population.

Land mammals were scarce. Two isolated Musk oxen Ovibos moschatus were present in the interior, and Snow hares Lepis arcticus were seen on a few occasions. Droppings and a few winter nests of Lemmings Dicrostonyx torquatus were found but not commonly. Wolf Canis lupus tracks were also seen, but no wolf was present during our stay. Interesting was the near total absence of Arctic foxes Alopex lagopus. Tracks and droppings of only a single animal were encountered 

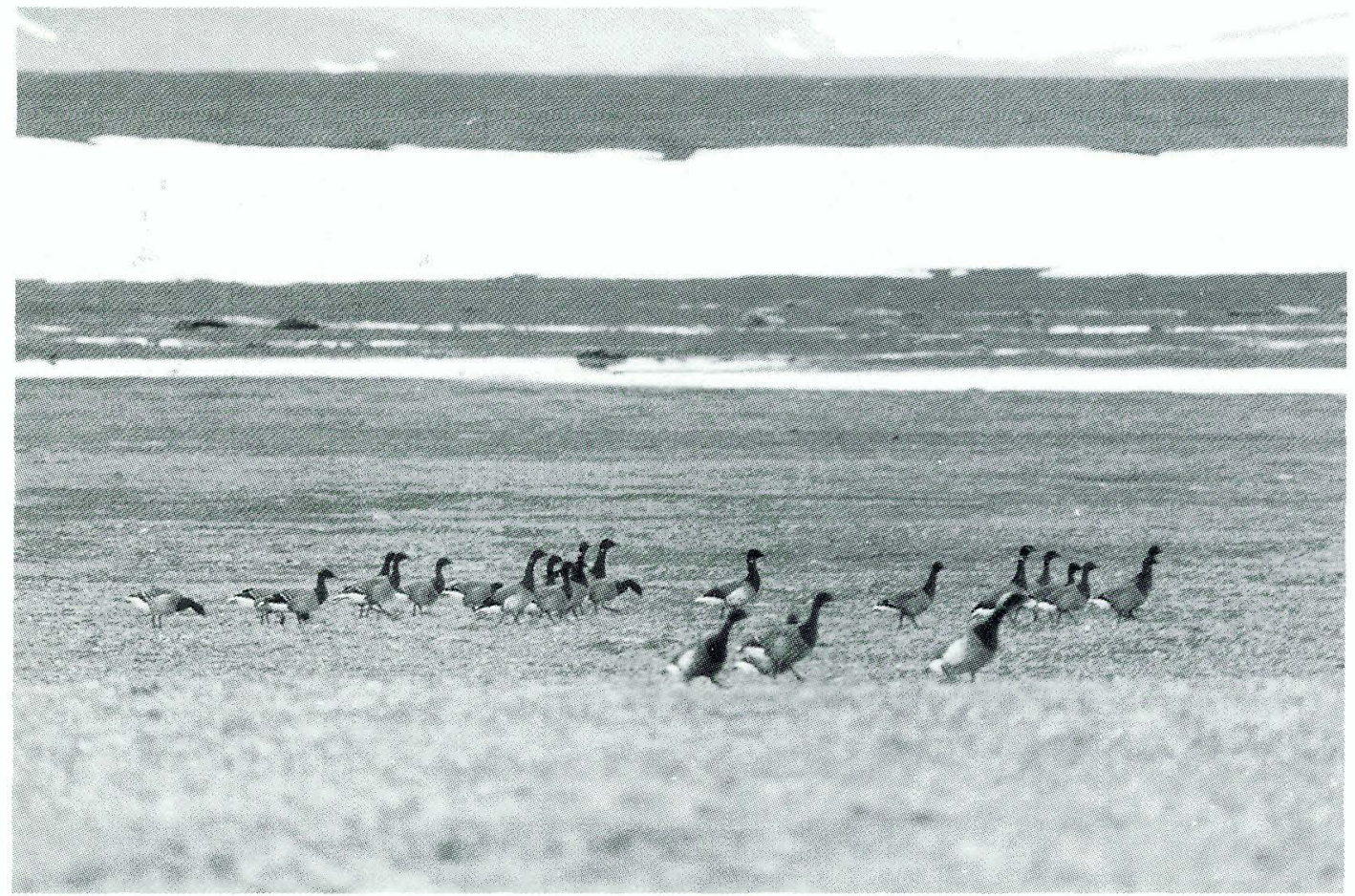

Fig. 10. Brent goose Branta leucopsis hrota feeding in the Alopecurus alpinus and Papaver radicatum vegetation centrally in the plains region. Note the high proportion of young, slightly smaller birds.

althogh the wet, clayey ground was perfect for the preservation of tracks. The reason for this unusual absence of foxes may lie in a combination of the physical isolation of Kilen (more than $20 \mathrm{~km}$ across the icecap to the nearest and equally small land area) and, probably, very poor survival possibilities during the winter. To complete the list a single observation of Ermine Mustela erminea from the mountainous area in 1980 should be mentioned; no ermines were seen in 1985.

\section{Birds}

The first ornithological observations ever made on Kilen were those carried out during our brief visits there in 1980 (Hjort et al. 1984). At that time, the important coastal areas were not studied. This was possible in 1985.

The most interesting ornithological finding on Kilen in 1985 was the large population of geese (Hjort et al. 1987), most notably an hitherto unknown breeding population of Brent goose Branta bernicla hrota. At least 850 birds were encountered, including a large proportion of young. The Brent goose has lately been regarded as more or less extinct in northeastern Greenland (Meltofte 1976). Only scattered observations have been made during the last decades and only one breeding record is known from this period (in 1978 on the nearby semi-nunatak Nakkehoved; Håkansson et al. 1981a). Important factors in explaining the existence of such a large isolated population of the ground nesting goose on Kilen may be the more or less total absence of foxes and the unusual dominance of suitable food plants in the vegetation (fig. 10).

Another notable goose observation in 1985 was that of 1 or 2 breeding pairs of Snow goose Anser caerulescens. This species breeds in NW Greenland and west thereof and has been observed several times in both eastern North Greenland and Northeast Greenland, but this was the first breeding record in these parts. An observation of 7 Barnacle geese Branta leucopsis constitutes the northernmost record to date of that species.

The breeding of the Common eider Somateria mollissima this far north was first discovered in 1980 (Hjort et al. 1984, 1988). It was further substantiated in 1985. At least 15 females with 
broods were observed in the delta near the Sirius hut (Fig. 1), and to this may be added a few broods further south along the coast and some nests that still had eggs, or had recently been predated.

An interesting occurrence was the loose breeding colonies of Sabine's gull Larus sabini along the coast, where they bred together with Arctic terns Sterna paradisaea. There were 20 or more pairs on the beach ridges and delta flats around the Sirius hut, and at least another 5 pairs $5 \mathrm{~km}$ to the south. In 1980 Sabine's gulls were also found breeding on some small islands further south in the polynya (Hjort et al. 1984, 1988).

Wader migration was monitored. Numbers were small and the dominating species were the Sanderling Calidris alba $(\sim 100)$ and the Knot Calidris canutus ( 60), followed by the Turnstone Arenaria interpres ( 30). Surprisingly, there was a small but steady trickle of Grey phalaropes Phalaropus fulicarius $(\sim 20)-$ a species that has never previously been found breeding in this area or north thereof. Two juvenile Baird's sandpipers Calidris bairdii were seen in late $\mathrm{Au}$ gust - representing another species which - like the Snow goose - breeds in NW Greenland and further west. The only wader of which we have more substantial breeding indications on Kilen is the Sanderling.

Observations along the coast included a small but steady passage of Fulmars Fulmarus glacialis, probably on their way to and from the breeding colonies further south along the polynya (Pedersen 1942; Hjort et al. 1984), a few Kittiwakes Rissa tridactyla and Glaucous gulls Larus hyperboreus, and one Greater black-backed gull Larus marinus. Ivory gulls Pagophila eburnea were common along the coast, especially late August (30-40 stationary birds in the delta by the Sirius hut), and they were still breeding in the colony found in the interior mountains in 1980 (Hjort et al. 1984).

Acknowledgements. Our accomplishments in Kilen were made possible through the good will and cooperation of a number of people, most notably State Geologist Niels Henriksen (Geological Survey of Greenland) and Major J. P. S. Clemmensen (Forsvarskommandoen).

The financial base of the expedition was secured through a grant from the Carlsberg Foundation, with two of the participants receiving additional financial support from the Ymer Foundation (Chr.Hj.) and the Danish Natural Science Research Council (T.B.). Field equipment was made available by GGU. An initial air-lift from Station Nord to the Sirius hut provided by Dr. Peter Rutschmann was essential in getting our activities under way. We are grateful to the above mentioned people and organisations.

\section{Dansk sammendrag}

Kilen Ekspeditionen 1985

Tove Birkelunds sidste indsats for udforskningen af Grønlands geologi fandt sted i sommeren 1985 inden for rammerne af en tværfaglig ekspedition til Kilen i Kronprins Christian Land. Her var hendes indsats koncentreret om dokumentationen af en rig ammonitfauna fra den indtil 1980 helt ukendte sekvens af $\emptyset$ vre Kridt sedimenter.

Kilen er en langstrakt semi-nunatak der skærer sig dybt ind i Flade Isblink umiddelbart syd for Nordostrundingen. Tidligere undersøgelser begrænser sig til kortvarige besøg i 1970 og 1980. De i 1980 indvundne erfaringer vedrørende Kilens særegne geologi og naturforhold iøvrigt var baggrunden for gennemførelsen af denne ekspedition - fortrinsvis financieret af Carlsbergfondet - med det specifikke formål at udforske Kilen.

Ekspeditionen konstaterede tilstedeværelsen af tæt ved $3,5 \mathrm{~km}$ klastiske, marine sedimenter fra perioden $\emptyset v r e$ Jura - $\emptyset v r e$ Kridt. Hele akkumulationen er foregået $\mathrm{i}$ lokale bassiner, $\mathrm{i}$ det store hele uafhængigt af udviklingen i de tilgrænsende områder af Grønland og Svalbard. Akkumulationshastigheden i $\emptyset$ vre Kridt (TuronienConiacien) har været betydelig, og specielt disse sedimenter indeholder en ret divers, velbevaret fauna. De strukturgeologiske undersøgelser har godtgjort, at $\emptyset$ vre Kridt sedimenterne akkumuleredes $\mathrm{i}$ et pull-apart bassin udviklet omkring grænsen imellem Nedre og $\emptyset$ vre Kridt i det regionale Wandel Hav Strike-Slip Mobile Belt. Fortsatte dextrale bevægelser $i$ dette bælte forårsagede i slutningen af $\emptyset_{v r e}$ Kridt en betydelig kompression, således at hele lagsøjlen på Kilen blev deformeret $i$ et komplekst mønster domineret af en èchelon domefolder og overskydninger.

Marine pleistocæne sedimenter af betydelig alder er bevaret lokalt. Forskellige dateringsmetoder kombineret med evidensen fra den fundne foraminifer-fauna sandsynligg $\varnothing \mathrm{r}$ et aflejringstidspunkt i Holstein interglacial perioden. Molluskfaunaens sammensætning viser, at aflejringen er foregået ved temperaturer over de, der hersker idag. Resultaterne af de øvrige kvartærgeologi- 
ske undersøgelser gør det rimeligt at antage, at Flade Isblink først er opbygget i Holocæn, samt at den er et helt lokalt fænomen, uden sammenhæng med Indlandsisens historie.

Vegetationsdækket på Kilen er generelt meget tyndt, og med et artstal på blot 34 afviger Kilens flora betydeligt fra de mere udstrakte landområder i Nordgrønland (Peary Land, Holm Land). Den artsfattige flora er bl.a. karakteriseret ved at mangle så almindelige højarktiske elementer som star og kæruld, samt alle dværgbuske - bortset fra en meget begrænset forekomst af arktisk pil. Fordelingen af arter inden for Kilen afspejler mikroklimatiske variationer, der fortrinsvis er styret af afstanden fra kysten, samt af højden. Polar-rævehale og fjeldvalmue er de dominerende arter $\mathrm{i}$ næsten alle plantesamfund. Sidstnævnte art optræder med både gulblomstrede og hvidblomstrede former - gule blomster er især knyttet til indlandet, medens hvidblomstrede planter dominerer $\mathrm{i}$ de stærkt tågepåvirkede kystnære områder.

Dyrelivet omkring Kilen er især knyttet til det åbne vand i Nordøstvandet Polynia'en, hvis nordlige del netop strækker sig frem til Kilens kyst. Vore besøg har således dokumenterert en lokal ynglebestand af såvel hvalros som isbjørn i forbindelse med polynia'en. I skarp kontrast hertil er indlandets dyreliv særdeles begrænset. Tilstedeværelsen af syv pattedyrarter er dokumenteret, men kun for tre af disse arter foreligger der direkte observationer: to moskus-okse, to snehare samt én hermelin. Regionens øvrige tre rovdyr polar-ræv, polar-ulv og isbjørn - har næppe fast ophold på Kilen.

Også fordelingen af fuglẹlivet på Kilen er præget af polynia'ens tilstedeværelse, med en overvægt af hav- og kysttilknyttede former blandt de ialt 29 arter, der er registreret. Den åbenbare mangel på andet end migrerende større landrovdyr giver baggrund for en ganske betydelig bestand af jordrugende gæs (langt overvejende knortegas) på de udstrakte, fugtige sletter, der optager største delen af Kilens areal. Herudover blev kun ganske få arter konstateret ynglende $\mathrm{i}$ de indre dele af Kilen, og kun i meget ringe antal.

\section{References}

Aleksandrova, V. D. 1988: Vegetation of the Soviet polar deserts. (Transl. by D. Löve of the Russian edition from 1983). Cambridge University Press, 228 pp.

Bay, C. 1992: Phytogeographical study of northern Greenland - north of $74^{\circ} \mathrm{N}$ lat. Meddr Gronland,-Bioscience 36, 102 pp.

Birkelund, T. \& Håkansson, E. 1983: The Cretaceous of North Greenland - a stratigraphic and biogeographical analysis. Zitteliana 10, 7-25.

Bromley, R. G. \& Gale, A. S. 1982: The lithostratigraphy of the English Chalk Rock. Cretaceous Research 3, 273-306.

Dawes, P. 1976: Precambrian to Tertiary of northern Greenland. In A. Escher \& W. S. Watt (Eds): Geology of Greenland. Geological Survey of Greenland, Copenhagen, 248 303.

Dawes, P. \& Soper, J. 1973: Pre-Quaternary history of North Greenland. In M. G. Pitcher (Ed.): Arctic Geology. Amer. Assoc. Petrol Geol. Mem. 19, 117-134.

Edlund, S. A. 1983: Bioclimatic Zonation in a High Arctic Region: Central Queen Elizabeth Islands. Current Research, Part A, Geological Survey of Canada, Paper 83-1A, 381-390.

Elvebakk, A. 1990: A new method for defining biogeographical zones in the Arctic. Arctic Research, advances and prospects. Proc. Conf. Arctic Nord. Count. Coord. Res. Arctic. Leningrad 1988, 175-186.

Feyling-Hanssen, R. W. 1990: A remarkable foraminiferal assemblage from the Quaternary of northeast Greenland. Bull. geol. Soc. Denmark 38, 101-107.

Haller, J. 1983: Geological map of Northeast Greenland 75$82^{\circ} \mathrm{N}$ Lat. 1:1.000.000. Meddr Grønland 200, 5, $22 \mathrm{pp}$.

Henriksen, N. \& Higgins, A. K. 1976: East Greenland Caledonian Foldbelt. In A. Escher \& W. S. Watt (Eds): Geology of Greenland. Geological Survey of Greenland, Copenhagen, 182-246.

Hjort, C. 1981: Quaternary geology in northeasternmost Greenland. In V. Schytt, K. Boström, \& C. Hjort: Geoscience during the Ymer-80 expedition to the Arctic. Geol. Fören. Stockholm Förh. 103, 114-115.

Hjort, C. 1988: Weichselian versus Flandrian glacial developments on Kilen, northeasternmost Greenland - a case of interglacial ice-cap expansion. 18. Nordiske Geologiske Vintermøde, København 1988. Abstracts, 165.

Hjort, C. \& Feyling-Hanssen, R. W. 1987: The Ymer-Formation - an interglacial sequence in northeasternmost Greenland. Polar Research 5 n.s., 347-350.

Hjort, C., Håkansson, E. \& Mølgaard, P. 1987: Brent Geese Branta bernicla Snow Geese Anser caerulescens and Barnacle Geese Branta leucopsis on Kilen, Kronprins Christian Land, Northeast Greenland, 1985. Dansk orn. Foren. Tidsskr. 81, 121-128.

Hjort, C., Håkansson, E. \& Mølgaard, P. 1988: Bird observations on Kilen, north-easternmost Greenland, 1985. Dansk orn. Foren. Tidsskr. 82, 19-24.

Hjort, C., Håkansson, E. \& Stemmerik, L. 1984: Bird observations around the Nordøstvandet polynya, Northeast Greenland, 1980. Dansk orn. Foren. Tidsskr. 77, 107-114.

Håkansson, E., Bennike, O., Mølgaard, P. \& Frykman, P. 1981a: Bird observations from northern Greenland in the summers of 1976 and 1978. Dansk orn. Foren. Tidsskr. 75. 51-67.

Håkansson, E., Heinberg, C. \& Stemmerik, L. 1981b: The Wandel Sea Basin from Holm Land to Lockwood $\emptyset$, eastern North Greenland. Rapp. Grønlands geol. Unders. 106, $47-63$.

Håkansson, E., Heinberg C. \& Stemmerik, L. 1991: Mesozoic 
and Cenozoic history of the Wandel Sea Basin area, North Greenland. Bull. Grønlands geol. Unders. 160, 153-164.

Håkansson, E. \& Pedersen, S. A. S. 1982: Late Paleozoic to Tertiary tectonic evolution of the continental margin in North Greenland. Can. Soc. Petrol. Geol. Mem. 8, 331348.

Håkansson, E., Pedersen, S. A. S. \& Zinck-Jørgensen; K. 1992: Structural styles of the Wandel Hav Strike-Slip Mobile Belt, North Greenland. Conf. Arctic Margins, Anchorage, Sept. 1992, Abstracts.

Håkansson, E. \& Stemmerik, L. 1989: Wandel Sea Basin - A new synthesis of the late Paleozoic to Tertiary accumulation North Greenland. Geology 17, 683-686.

Håkansson, S. 1982: University of Lund Radiocarbon datings XV. Radiocarbon 24, 194-213.

Kevan, P. G. 1972: Floral colors in the high arctic with reference to insect-flower relations and pollination. Canadian Journal of Botany 50, 2289-2316.

Knuth, E. 1942: Report on the expedition and on subsequent work at the Mørkefjord station. Meddr Grønland 126,1, $159 \mathrm{pp}$.

Lowell, 1972: Spitsbergen Tertiary Orogenic Belt and the Spitsbergen Fracture Zone. Geol. Soc. Am. Bull. 83, 30913102.

Meltofte, H. 1976: Ornithological observations in southern Peary Land, North Greenland, 1973. Meddr Grønland 205,1, $57 \mathrm{pp}$.

Mølgaard, P. 1989: Temperature relations of yellow and white flowered Papaver radicatum in North Greenland. Arctic and Alpine Research 21, 83-90.
Neergaard, E. de 1985: Svalbard, en vegetationsmæssig forpost. Urt 1985,3, 71-75.

Nielsen, E. 1941: Remarks on the map and geology of Kronprins Christians Land. Meddr Gronland 126,2, 34 pp.

Pedersen, A. 1942: Säugtiere und Vögel. Dansk Nordøstgrønlands Expedition 1938-39. Meddr Grønland 128,2, 119 pp.

Pedersen, S. 1988: Model of structural events in the Late Mesozoic platform break up between Greenland and Svalbard. Rapp. Norsk Polarinst. 46, 99-100.

Rannie, W. F. 1986: Summer Air Temperature and Number of Vascular Species in Arctic Canada. Arctic 39, 133-137.

Rodgers, D. A. 1980: Analysis of pull-apart basin development produced by en èchelon strike-slip faults. Spec. Publ. int. Ass. Sediment. 4, 27-41.

Soper, N. J., Dawes, P. R. \& Higgins, A. K. 1982: CretaceousTertiary magmatic and tectonic events in North Greenland, and the history of adjacent ocean basins. In P. R. Dawes \& J. W. Kerr $(E d s)$ : Nares Strait and the drift of Greenland; a conflict in plate tectonics. Meddr Gronland, Geosci. 8, 205-220.

Swift, J. P. D., Figueiredo, A. G., Freeland, G. L. and Oertel, G. F. 1983: Hummocky cross-stratification and megaripples: A geological double standard? J. Sed. Petrol. 53, 1295-1317.

Walker, R. G. 1975: Generalized facies models for resedimented conglomerates of turbidite association. Geol. Soc. Am. Bull. 86, 737-748.

Wright, C. W. 1979: The ammonites of the English Chalk Rock (Upper Turonian). Bull. Br. Mus. nat. Hist. (Geol.) 31 (4), 281-332. 